\title{
Characteristics of Heavy Metal Ion Adsorption by Silty Mudstones in Coal Mine Goafs
}

\author{
Qiang-ling Yao, ${ }^{1,2}$ Ze Xia $\mathbb{D}^{1,},{ }^{1,2}$ Chuan-jin Tang, ${ }^{1,2}$ Liu Zhu, ${ }^{1,2}$ Wei-nan Wang, ${ }^{1,2}$ Tian Chen, ${ }^{3}$ \\ and Ying-ming $\operatorname{Tan}^{1,2}$ \\ ${ }^{1}$ Key Laboratory of Deep Coal Resource Mining (CUMT), Ministry of Education, Xuzhou 221008, China \\ ${ }^{2}$ School of Mines, China University of Mining \& Technology, Xuzhou 221116, China \\ ${ }^{3}$ School of Mechanical, Aerospace and Civil Engineering, The University of Manchester, Manchester M13 9PL, UK
}

Correspondence should be addressed to Ze Xia; xiaze19941004@163.com

Received 15 July 2019; Accepted 21 January 2020; Published 12 February 2020

Academic Editor: Paolo Madonia

Copyright (c) 2020 Qiang-ling Yao et al. This is an open access article distributed under the Creative Commons Attribution License, which permits unrestricted use, distribution, and reproduction in any medium, provided the original work is properly cited.

\begin{abstract}
Coal mine goafs can be used to store and purify mine water; therefore, they are important for mitigating the environmental impact of mining on ecologically fragile areas in Western China. Coal gangue in goafs can reduce turbidity, suspended matter, total hardness, and chemical oxygen demand (COD) in mine wastewater. Because gangue in goaf areas is rich in clay minerals, they serve as ion exchange sites. We investigated the adsorption of heavy metal ions by silty mudstones in the Ulan Mulun mine. The adsorption kinetics and isothermal adsorption characteristics of four heavy metal ions, i.e., $\mathrm{Pb}(\mathrm{II})$, $\mathrm{Cd}(\mathrm{II}), \mathrm{Cr}(\mathrm{III})$, and $\mathrm{Mn}(\mathrm{II})$, were investigated using batch experiments. Under a $\mathrm{pH}$ of 6.75 and temperature of $20^{\circ} \mathrm{C}$, the adsorption capacity of silty mudstone particles $(<74 \mu \mathrm{m})$ was $6.3012 \mathrm{~g}, 1.5701,1.2571$, and $1.3729 \mathrm{mg} / \mathrm{g} \mathrm{for} \mathrm{Pb}(\mathrm{II}), \mathrm{Cd}(\mathrm{II})$, $\mathrm{Cr}(\mathrm{III})$, and $\mathrm{Mn}(\mathrm{II})$, respectively. Based on the experimental results, quantitative relationships between the adsorption quantity per unit of rock surface and the equilibrium concentration of heavy metals in solution were developed using Langmuir, Freundlich, and D-R equations. The relationships were used to obtain the equilibrium concentration of the solution. Finally, the ratio of the $f$ value of the water-rock contact area in the goaf to the water volume was calculated and analyzed. The $f$ value was inversely proportional to the average vertical opening of gaps between gangues in the goaf. The adsorption rate functions for $\mathrm{Pb}(\mathrm{II}), \mathrm{Cd}(\mathrm{II}), \mathrm{Cr}(\mathrm{III})$, and $\mathrm{Mn}(\mathrm{II})$ in the goaf were obtained, and the corresponding adsorption capacities were calculated. The adsorption capacities were controlled by the $f$ value and adsorption properties of the gangue. These results can be used in future studies on mine wastewater treatment.
\end{abstract}

\section{Introduction}

The rapid growth of mining, metal plating, tanning, and battery manufacturing industries has resulted in increased environmental pollution [1]. Heavy metal pollution is a serious concern because of its toxicity and threat to humans, animals, and plants $[2,3]$. Adsorption of heavy metals is a simple and cheap method for water purification. Clay minerals are widespread in nature and strongly affect the permeability, mechanics, and porewater chemistry of soils, sediments, and rocks $[4,5]$. Because they contain active amphoteric hydroxyl groups, negative charge structures, and large specific surface areas, clay minerals are important adsorbents for metals and radioactive contaminants in the natural environment [6-9]. Therefore, the use of clay minerals, such as kaolinite, illite, montmorillonite, and chlorite, as an economical and effective adsorption material for heavy metals ( $\mathrm{Pb}(\mathrm{II}), \mathrm{Cd}(\mathrm{II}), \mathrm{M}(\mathrm{II}), \mathrm{Cr}(\mathrm{VI}), \mathrm{Co}(\mathrm{II})$, etc.) has been widely studied [10-16].

Coal mining in Western China requires a large amount of water resources, but the existing water supply cannot satisfy the water demand in mining areas. The exploitation of coal 
resources has caused the destruction of overlying aquifers and massive loss of water resources. Hence, it is crucial to develop new technology to rationally store and utilize wastewater produced by coal mining. Ma et al. [17] proposed a technology of constructing groundwater reservoirs in goafs of shallow coalfields to protect fragile ecological environments to maintain a sustainable development in the Shenfu-Dongsheng coalfield.

Industrial practice has shown that waste rocks in goafs exhibit a strong purification effect on sewage by improving characteristics such as turbidity, suspended solids, ammonia nitrogen, chloride, total hardness, bacteria, and COD; additionally, purified water can satisfy the demands of industrial and green water. Waste rocks can reduce water turbidity by more than $90 \%$, whereas the reduction effect of traditional processes is generally $80 \%-90 \%$ [18]. The removal of iron and turbidity from mined-out areas is high, but manganese removal is limited by the adsorption saturation of rocks $[19,20]$. Typical coal waste rocks contain $50 \%-70 \%$ clay minerals (illite, kaolinite, chlorite, illite-smectite, etc.), $20 \%-30 \%$ quartz, and 10\%-20\% other minerals and carbon impurities [21]. As a treatment method, heavy metalcontaminated water can be discharged into abandoned goafs, where clay minerals will remove heavy metal ions via adsorption. As few studies have focused on heavy metal removal in goafs, it is critical to investigate this topic.

\section{Engineering Background}

Mine water storage and utilization are typical practices to mitigate the loss of mine water effluent in the Shendong mining area. The Ulan Mulun coal mine, a main shaft of the Shenhua Shendong Coal Group Company in China, is one of the earliest mines to practice water storage in mined-out areas. The Ulan Mulun coal mine is located in the eastern Ordos Plateau at the edge of the Mu Us desert. The area is dominated by aeolian desert.

Water resources are limited in the Ulan Mulun mining area, and high-intensity coal mining has inevitably destroyed the aquifer. To retain water, the practice of "goaf water storage" has been implemented in the Ulan Mulun mine, whereby the mined-out area formed during coal exploitation is used as an underground reservoir to store mine water. It was discovered that mined rock imposed a natural purification effect on wastewater. Typically, purified water is partly used for underground and surface water production, and the remaining is stored as a reserve for aquifer restoration and the surface environment. Compared with artificial purification practices, underground reservoir systems save money, avoid the waste of water resources, and hence offer significant economic and ecological benefits.

The overlying fissure water and underground wastewater caused by mining in the Ulan Mulun mine are classified and stored in different underground reservoirs. We investigated the feasibility of using goaf waste rocks to treat heavy metal-contaminated wastewater. Because heavy metal concentrations in coal wastewater from the Mulun Ulan mine are below detectable limits, we could not directly verify the purification effect of goafs on heavy metal ions in this study.
However, as toxic elements in mine water are a serious threat $[22,23]$, this study is important for evaluating the potential of goaf purification systems.

\section{Materials and Methods}

\subsection{Experimental Materials}

3.1.1. Waste Rock Composition and Microstructure Characteristics. The No. 3-1 coal panel (see Figure 1) is the main water storage area in the Ulan Mulun coal mine. The roof and floor consist of silty mudstones, whereas waste rocks in goaf primarily consist of silty mudstones. Rock samples were collected from the 31409 face of the coal mine. The natural moisture content of the samples was $6 \%$, and the water saturation ratio was $4.3 \%$. Some rock samples were crushed and sieved through a 200mesh sieve (74 $\mu \mathrm{m}$; group A samples; see Figure 2(a)), and the remaining was formed into cylindrical specimens of diameter $25 \mathrm{~mm}$ and height $10-30 \mathrm{~mm}$ (group B samples; Figure 2(b)).

A D8 Advance-type X-ray diffractometer (Bruker Co., Germany) was used for the X-ray diffraction analysis of the silty mudstone (Figure 3 ).

The main minerals in the silty mudstone samples include halloysite and $\alpha$-quartz (low quartz), and the main impurities include glauconite $\left[\mathrm{K}(\mathrm{Al}, \mathrm{Fe}, \mathrm{Mg})_{2} \mathrm{Si}_{4} \mathrm{O}_{10}(\mathrm{OH})_{2}\right]$, chamosite $\left[(\mathrm{Fe}, \mathrm{Al}, \mathrm{Mg}, \mathrm{Mn})_{6}(\mathrm{Si}, \mathrm{Al})_{4} \mathrm{O}_{10}(\mathrm{OH})_{8}\right]$, clintonite [Ca(Mg,Al,$\left.\mathrm{Fe})_{3}(\mathrm{Al}, \mathrm{Si})_{4} \mathrm{O}_{10}(\mathrm{OH})_{2}\right]$, and albite $\left[\mathrm{Na}\left(\mathrm{Si}_{3} \mathrm{Al}\right) \mathrm{O}_{8}\right]$. Small amounts of $\mathrm{Al}-\mathrm{Ti}-\mathrm{Fe}, \mathrm{Al}-\mathrm{Ti}-\mathrm{Mn}, \mathrm{Ti}-\mathrm{Zr}-\mathrm{Al}$, and other intermetallic compounds and oxides were measured in the samples. The main components of the silty mudstone were $\mathrm{SiO}_{2}$ and $\mathrm{Al}_{2} \mathrm{O}_{3}$ (Table 1).

Scanning electron microscopy (SEM) images of the surface of the silty mudstone were produced using an FEI Quanta ${ }^{\mathrm{TM}} 250$ type electron microscope scanner (Figure 3). At low magnifications, the surface of the silty mudstone appears rough with deep depressions, loose particles, and layered accumulations (Figure 4(a)). The overall particle size is relatively uniform, and particle contact is primarily via point contact. The intergranular void exhibited indicates the large specific surface area of the silty mudstone, which is conducive to adsorption. At high magnifications, the argillaceous siltstone is rich in clay minerals and the rock surface is dominated by halloysite with small particles and poor crystallinity (Figure 4(b)).

3.1.2. Preparation of Heavy Metal Solution. The heavy metal solutions used in the experiment were prepared with $\mathrm{Pb}\left(\mathrm{NO}_{3}\right)_{2}, \mathrm{MnCl}_{2} \cdot 4 \mathrm{H}_{2} \mathrm{O}, \mathrm{CrCl}_{3} \cdot 6 \mathrm{H}_{2} \mathrm{O}$, and $\mathrm{CdCl}_{2} \cdot 2.5 \mathrm{H}_{2} \mathrm{O}$. All chemical reagents were of analytical grade. The solution $\mathrm{pH}$ was adjusted using $\mathrm{HNO}_{3}$ or $\mathrm{NaOH}$, and the ionic strength was adjusted using $\mathrm{NaNO}_{3}$. The water used in the experiments was secondary deionized water with a resistivity of $18.25 \mathrm{M} \Omega \cdot \mathrm{cm}$. Prior to the experiment, $0.1614 \mathrm{~g}$ of $\mathrm{Pb}\left(\mathrm{NO}_{3}\right)_{2}, \quad 0.2052 \mathrm{~g}$ of $\mathrm{CdCl}_{2} \cdot 2.5 \mathrm{H}_{2} \mathrm{O}, \quad 0.5175 \mathrm{~g}$ of $\mathrm{CrCl}_{3} \cdot 6 \mathrm{H}_{2} \mathrm{O}$, and $0.3639 \mathrm{~g}$ of $\mathrm{MnCl}_{2} \cdot 4 \mathrm{H}_{2} \mathrm{O}$ were separately dissolved in $100 \mathrm{~g}$ of water to prepare four heavy metal 

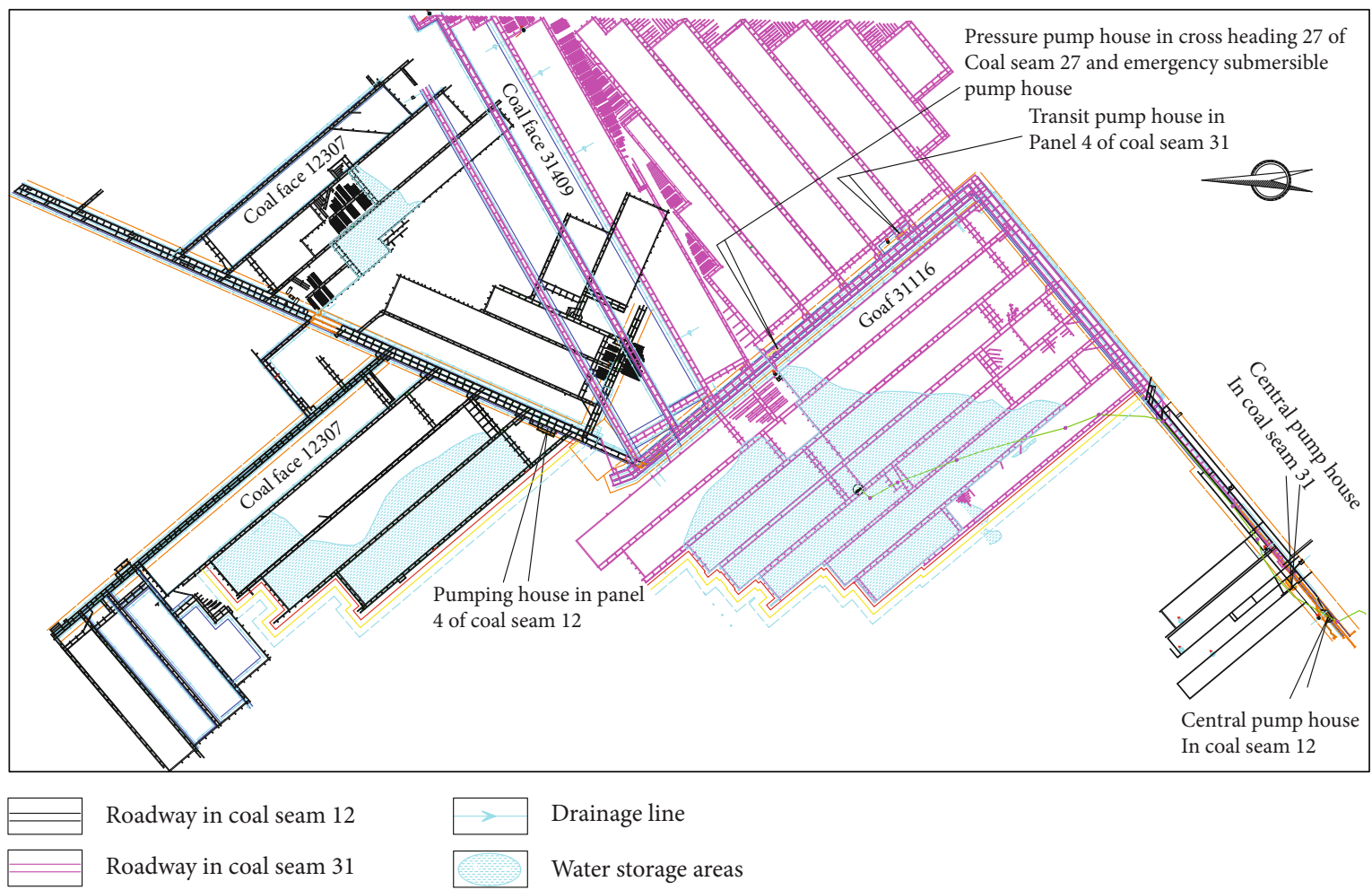

Supply line

(a)

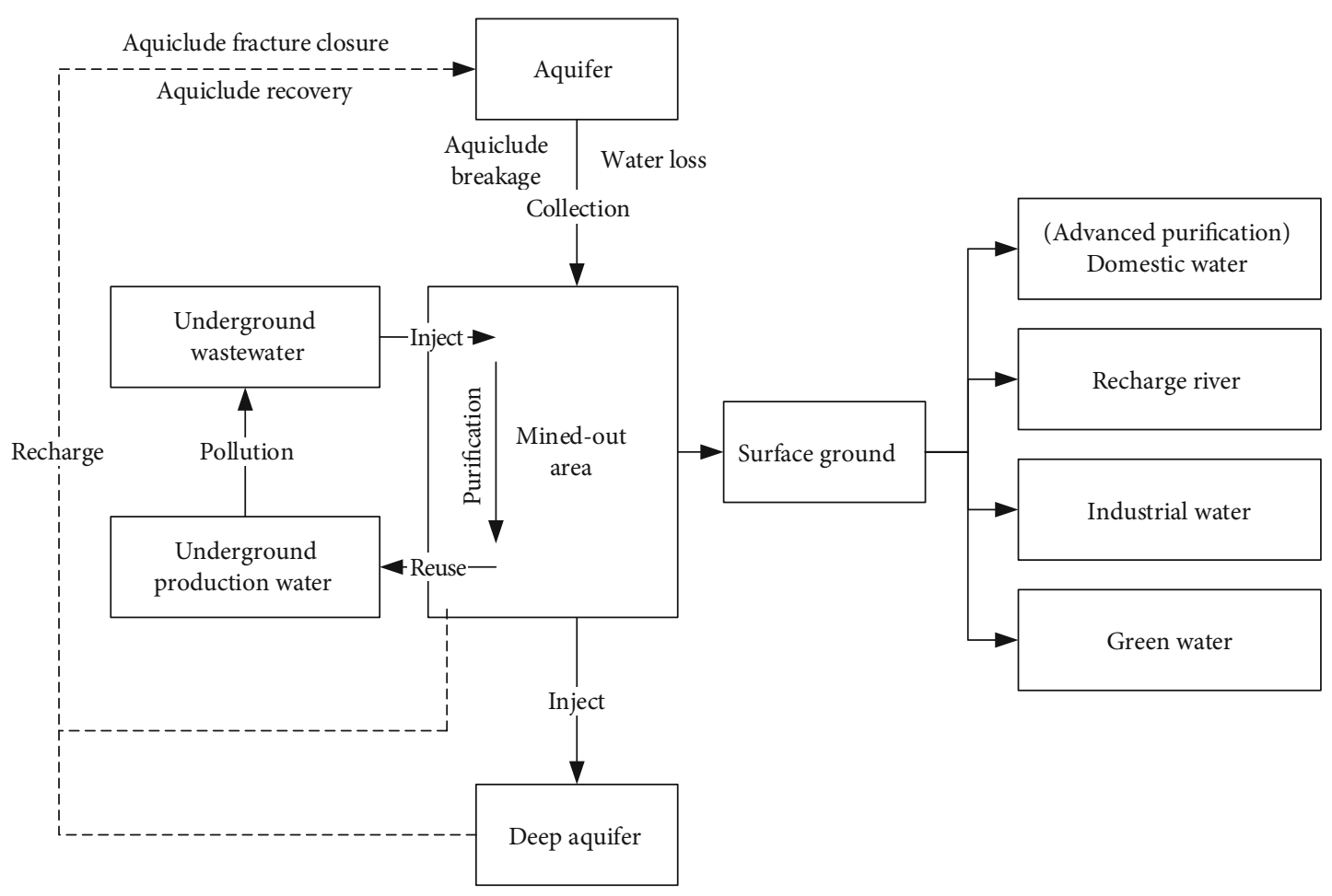

Note:

- - - Unrealized part

(b)

FIgURE 1: Layout and concept of goaf water storage. 


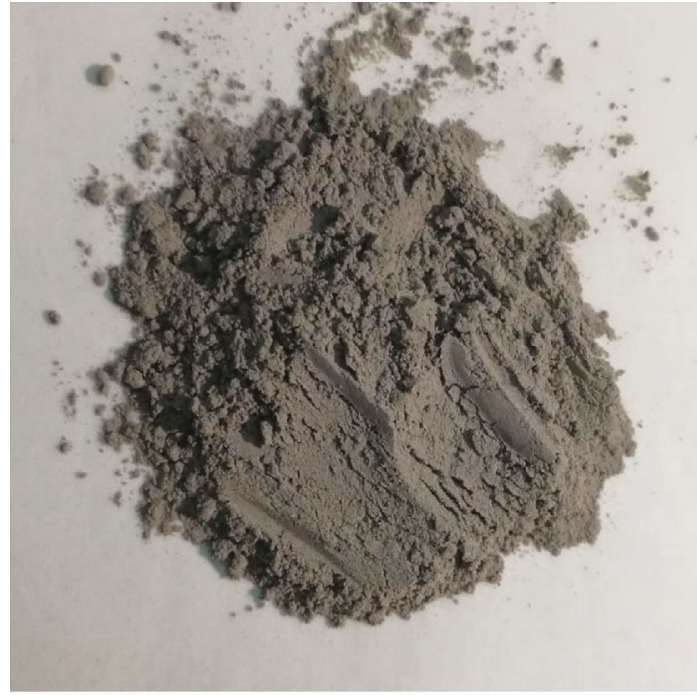

(a) Group A samples

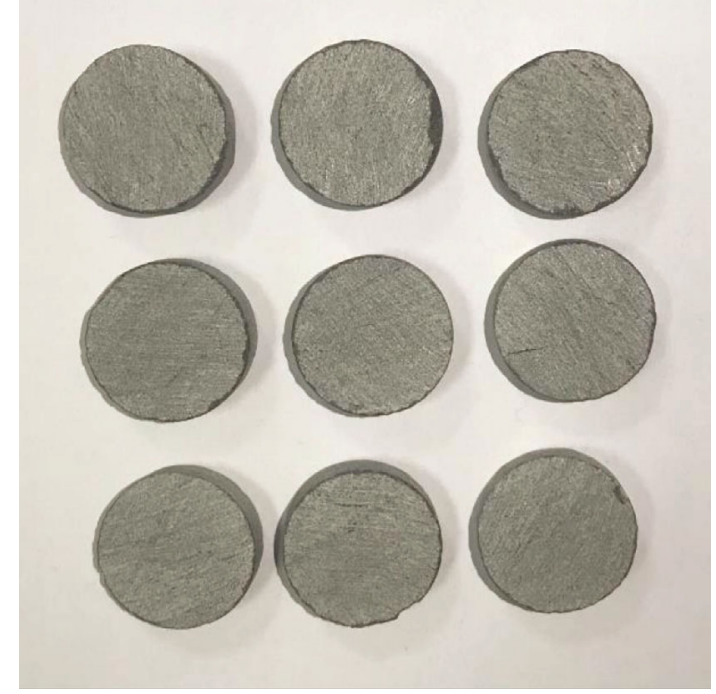

(b) Group B samples

Figure 2: Specimen samples.

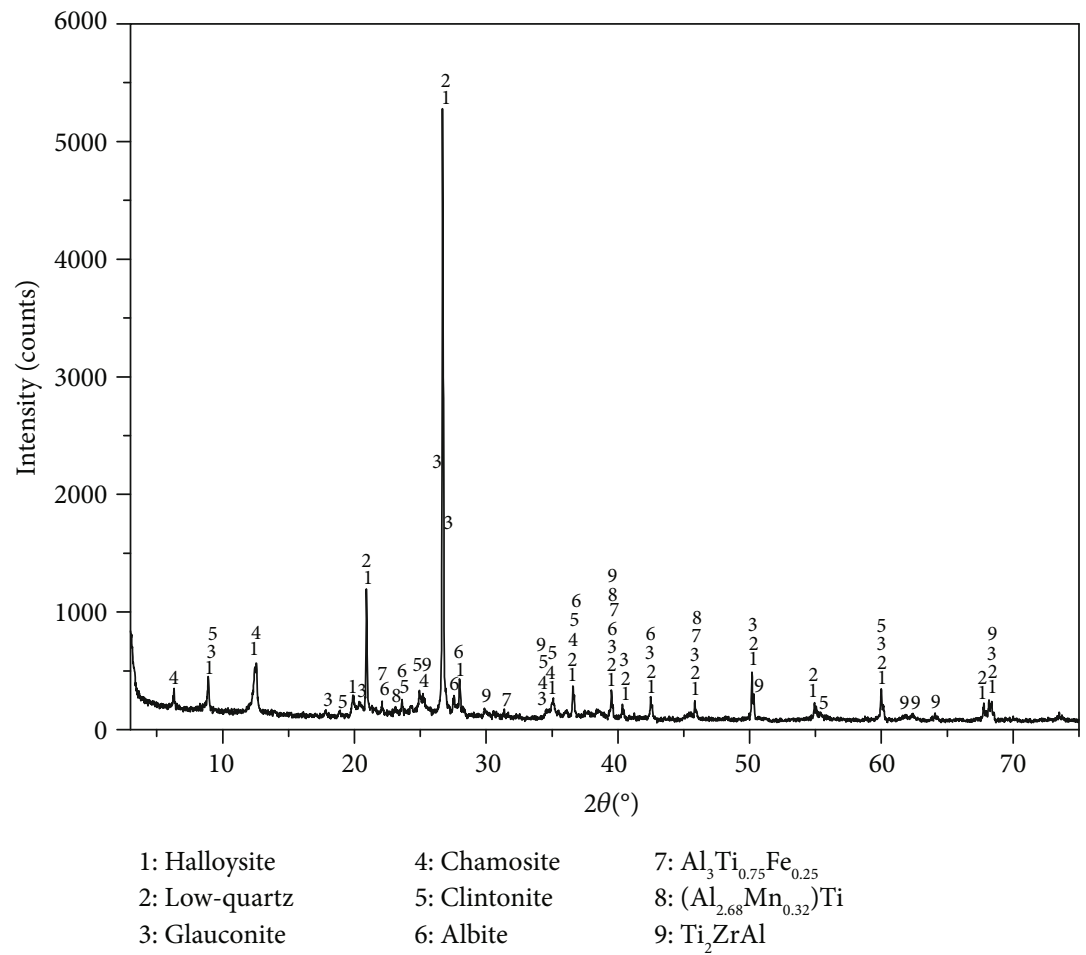

Figure 3: X-ray diffraction diagram of silty mudstone.

TABLE 1: XRF analysis of silty mudstone.

\begin{tabular}{lccccccc}
\hline Molecular formula & $\mathrm{SiO}_{2}$ & $\mathrm{Al}_{2} \mathrm{O}_{3}$ & $\mathrm{Fe}_{2} \mathrm{O}_{3}$ & $\mathrm{~K}_{2} \mathrm{O}$ & $\mathrm{MgO}$ & $\mathrm{Na}_{2} \mathrm{O}$ & $\mathrm{TiO}_{2}$ \\
Content (\%) & 65.264 & 24.686 & 3.393 & 3.116 & 1.357 & 0.941 & 0.854 \\
Molecular formula & $\mathrm{CaO}$ & $\mathrm{Ba}$ & $\mathrm{P}$ & $\mathrm{S}$ & $\mathrm{Zr}$ & $\mathrm{Mn}$ \\
Content (\%) & 0.237 & 0.056 & 0.035 & 0.029 & 0.016 & 0.016 \\
\hline
\end{tabular}




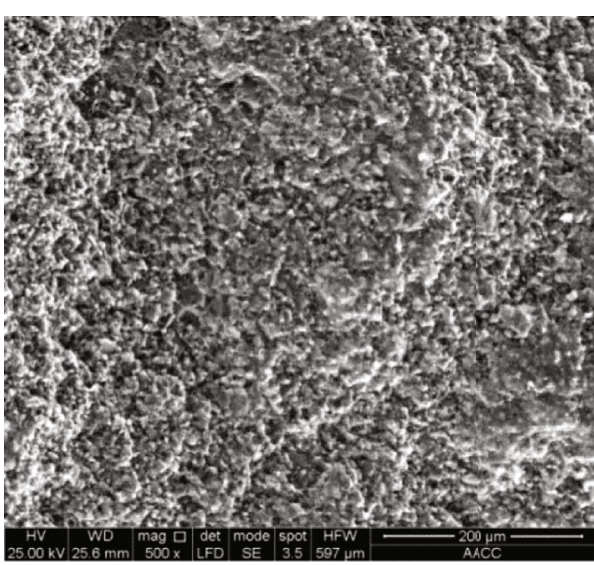

(a) 5000-fold

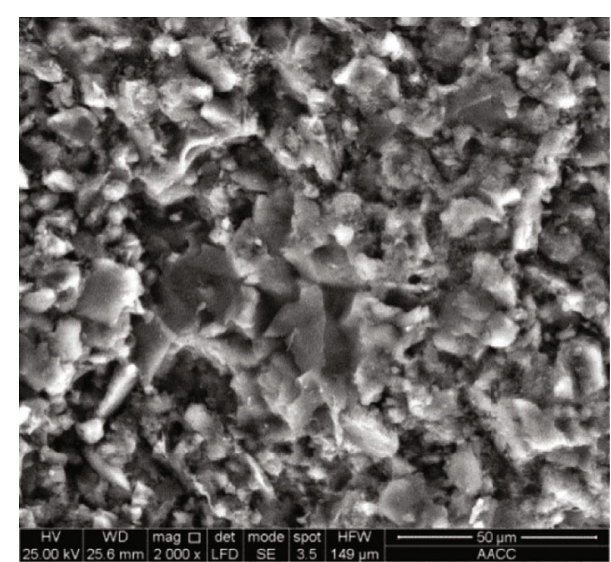

(b) 2000-fold

FIGURE 4: SEM images of silty mudstone.

solutions of concentration $1000 \mathrm{~g} / \mathrm{L}$. Deionized water was used to dilute the solutions to the required experimental concentrations when required.

\subsection{Experimental Methods}

3.2.1. Particle Samples. Adsorption kinetic and isothermal adsorption experiments were conducted to investigate the characteristics of $\mathrm{Pb}(\mathrm{II}), \mathrm{Cd}(\mathrm{II}), \mathrm{Cr}(\mathrm{III})$, and $\mathrm{Mn}$ (II) adsorption by silty mudstones. Reactions were conducted in $250 \mathrm{~mL}$ polyethylene conical vessels filled with $200 \mathrm{~mL}$ of heavy metal solution. The solid-liquid ratio for $\mathrm{Pb}(\mathrm{II}), \mathrm{Cd}(\mathrm{II})$, and $\mathrm{Cr}$ (III) was $1: 1000$, and the ratio for $\mathrm{Mn}$ (II) was $1: 200$. The temperature and $\mathrm{pH}$ were fixed at $20^{\circ} \mathrm{C}$ and 6.75 , respectively, and the background ion was $0.01 \mathrm{~mol} / \mathrm{L} \mathrm{NaNO}_{3}$. In the adsorption kinetics experiment, the reaction time was 0-360 min, and two different initial ion concentrations were used. In the isothermal adsorption experiment, the reaction time was $6 \mathrm{~h}$, and the initial concentrations of $\mathrm{Pb}(\mathrm{II}), \mathrm{Cd}(\mathrm{II})$, $\mathrm{Cr}(\mathrm{III})$, and $\mathrm{Mn}(\mathrm{II})$ were $0-20,0-10,0-10$, and $0-15 \mathrm{mg} / \mathrm{L}$, respectively. The main experimental procedures were as follows. (1) The conical vessels were soaked with $10 \%$ $\mathrm{HNO}_{3}$ for $24 \mathrm{~h}$ and rinsed with deionized water thrice. (2) Heavy metal ion solutions were prepared and individually mixed with silty mudstone samples in separate reaction vessels, which were placed in a horizontal reciprocating oscillator at a frequency of $180 \mathrm{rpm}$ and amplitude of $30 \mathrm{~mm}$. (3) The samples were collected after the prescribed time, filtered through $0.45 \mu \mathrm{m}$ nylon membranes, and stored in polyethylene tubes. The concentration of heavy metal ions in the water samples was detected by an Icp-oes (OPTIMA8000) spectrograph.

The equilibrium adsorption quantity $(\mathrm{mg} / \mathrm{g})$ of heavy metal ions per unit mass of silty mudstone was calculated using the following formula [24]:

$$
q_{\mathrm{e}}=\frac{\left(C_{0}-C_{\mathrm{e}}\right) V}{m}
$$

where $C_{0}(\mathrm{mg} / \mathrm{L})$ is the heavy metal concentration in solution before the reaction, $C_{e}(\mathrm{mg} / \mathrm{L})$ is the heavy metal concentra- tion in solution when the reaction is in equilibrium, $V(\mathrm{~L})$ is the volume of the solution, and $m(\mathrm{~g})$ is the mass of the silty mudstone.

3.2.2. Cylindrical Specimen Experiment. Six groups of cylindrical samples were used in this experiment: one group for $\mathrm{Pb}$ (II) and $\mathrm{Cr}$ (III) and two groups for $\mathrm{Cd}(\mathrm{II})$ and $\mathrm{Mn}$ (II). The reaction time was $24 \mathrm{~h}$, and other conditions were the same as those used in the isothermal adsorption experiment.

Assuming that the adsorption reaction primarily occurred on the outer surface of the samples, the equilibrium adsorption capacity $q_{\mathrm{es}}\left(\mathrm{mg} / \mathrm{dm}^{2}\right)$ of heavy metal ions in the silty mudstone per unit surface area was calculated according to the following formula:

$$
q_{\mathrm{es}}=\frac{\left(C_{0}-C_{\mathrm{e}}\right) V}{S}
$$

where $S\left(\mathrm{dm}^{2}\right)$ is the surface area of the rock sample (smooth rock surface).

\section{Adsorption Characteristics of Silty Mudstone}

4.1. Adsorption Kinetics. As shown in Figure 5, the adsorption of $\mathrm{Pb}(\mathrm{II}), \mathrm{Cd}(\mathrm{II}), \mathrm{Cr}(\mathrm{III})$, and $\mathrm{Mn}(\mathrm{II})$ by the silty mudstone particles was fast and occurred primarily during the first $15 \mathrm{~min}$ of the reaction. The $\mathrm{Pb}(\mathrm{II})$ and $\mathrm{Cd}(\mathrm{II})$ adsorption reactions reached equilibrium after $60 \mathrm{~min}$; the $\mathrm{Cr}(\mathrm{III})$ and $\mathrm{Mn}(\mathrm{II})$ adsorption reactions reached equilibrium at $180 \mathrm{~min}$ and $15 \mathrm{~min}$, respectively. After reaching equilibrium, the adsorption capacities fluctuated but remained constant in general. The equilibrium adsorption quantity of each heavy metal ion increased with the initial concentration.

4.2. Isothermal Adsorption Characteristics. As shown in Figure 6, the silty mudstone particles demonstrated strong adsorption capacity for all four heavy metals. As the initial concentrations of heavy metal solutions increased, the absorption capacities gradually increased to saturation, whereas the adsorption percentages gradually decreased. 


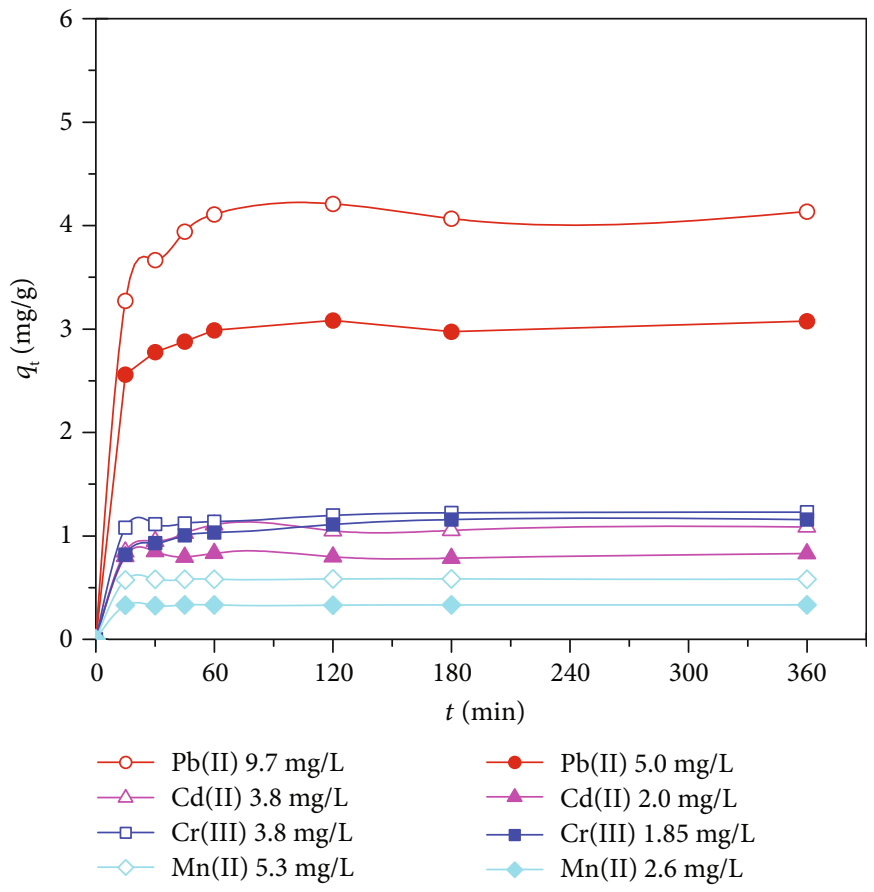

FIGURE 5: Adsorption capacity versus time.

When the initial concentration of $\mathrm{Pb}$ (II) increased from 1.4 to $20.3 \mathrm{mg} / \mathrm{L}$, the adsorption capacity increased from 1.26 to $6.04 \mathrm{mg} / \mathrm{g}$ and the adsorption rate decreased from $89.4 \%$ to $29.8 \%$. When the initial concentration of Cd(II) increased from 1.145 to $9.012 \mathrm{mg} / \mathrm{L}$, the adsorption capacity increased from 0.614 to $1.407 \mathrm{mg} / \mathrm{g}$ and the adsorption rate decreased from $53.62 \%$ to $15.61 \%$. When the initial concentration of $\mathrm{Cr}$ (III) increased from 0.944 to $9.781 \mathrm{mg} / \mathrm{L}$, the adsorption capacity increased from 0.91 to $1.25 \mathrm{mg} / \mathrm{g}$ and the adsorption rate decreased from $97.22 \%$ to $12.83 \%$. When the initial concentration of $\mathrm{Mn}$ (II) increased from 1.503 to $13.610 \mathrm{mg} / \mathrm{L}$, the adsorption capacity increased from 0.213 to $1.021 \mathrm{mg} / \mathrm{g}$ and the adsorption rate decreased from $70.7 \%$ to $37.5 \%$.

Langmuir, Freundlich, and Dubinin-Radushkevich (DR) models were employed to fit the experimental isothermal adsorption data. In the Langmuir model, the adsorption isotherm is described by a monolayer adsorption formula deduced from kinetic theory [25]:

$$
q_{\mathrm{e}}=\frac{b q_{\mathrm{m}} C_{\mathrm{e}}}{1+b C_{\mathrm{e}}},
$$

where $q_{\mathrm{e}}(\mathrm{mg} / \mathrm{g})$ is the mass of heavy metal ions absorbed per unit mass, $C_{\mathrm{e}}(\mathrm{mg} / \mathrm{L})$ the equilibrium concentration of metal ions in solution, $q_{\mathrm{m}}(\mathrm{mg} / \mathrm{g})$ the maximum adsorption capacity of heavy metal ions per unit mass, and $b(\mathrm{~L} / \mathrm{mg})$ a constant.

Formula (3) is typically represented as a linear relationship between $C_{\mathrm{e}} / q_{\mathrm{e}}$ and $C_{\mathrm{e}}$ :

$$
\frac{C_{\mathrm{e}}}{q_{\mathrm{e}}}=\frac{1}{b Q}+\frac{C_{\mathrm{e}}}{Q} .
$$

The Freundlich [26] isothermal formula is an empirical formula with the following exponential form:

$$
q_{\mathrm{e}}=K_{\mathrm{f}} C_{\mathrm{e}}^{1 / n}
$$

where $K_{\mathrm{f}}$ is the Freundlich constant related to the amount of adsorption, and $n$ is an empirical constant [5] related to the adsorption intensity. The linear form of the model can be expressed as follows:

$$
\ln q_{\mathrm{e}}=\ln K_{\mathrm{f}}+\frac{1}{n} \ln C_{\mathrm{e}} .
$$

The D-R model [27] is based on the micropore filling mechanism on a surface with an uneven energy distribution. The equation is as follows:

$$
q_{\mathrm{e}}=q_{\max } \exp \left(-k \varepsilon^{2}\right)
$$

where $q_{\max }\left(\mathrm{mol} \cdot \mathrm{g}^{-1}\right)$ is the maximum adsorption capacity, $k$ $\left(\mathrm{kJ} / \mathrm{mol}^{2}\right)$ a constant related to the adsorption energy, and $\varepsilon$ the Polanyi adsorption potential, which is calculated according to the following formula:

$$
\varepsilon=R T \ln \left(1+\frac{1}{C_{\mathrm{e}}}\right)
$$

where $R$ is a universal gas constant $\left(8.314 \times 10^{-3} \mathrm{~kJ} \mathrm{~mol}^{-1} \mathrm{~K}^{-1}\right)$, and $T(\mathrm{~K})$ is the temperature. The unit of $C_{\mathrm{e}}$ in this formula is 


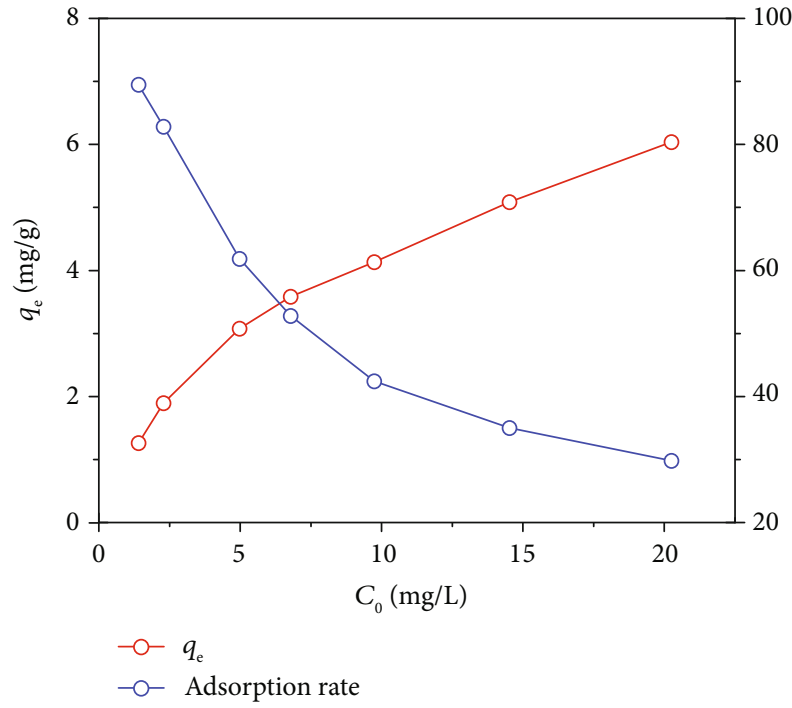

(a)

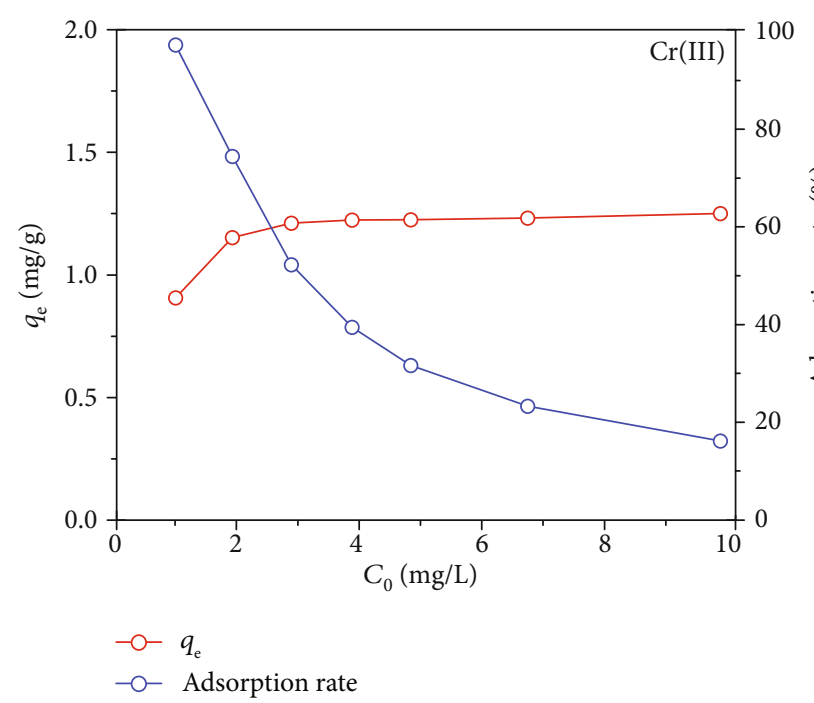

(c)

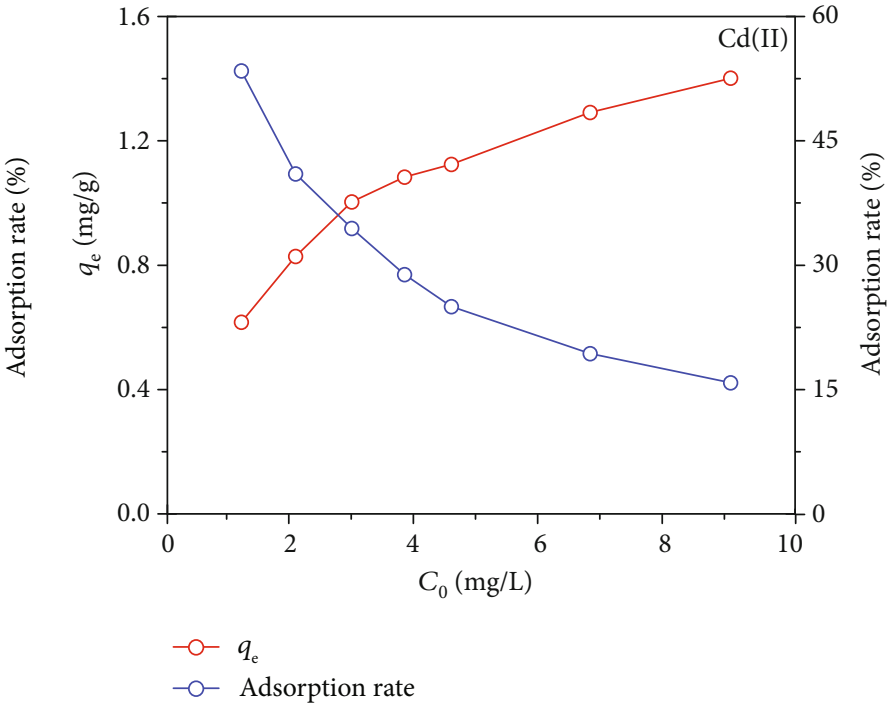

(b)

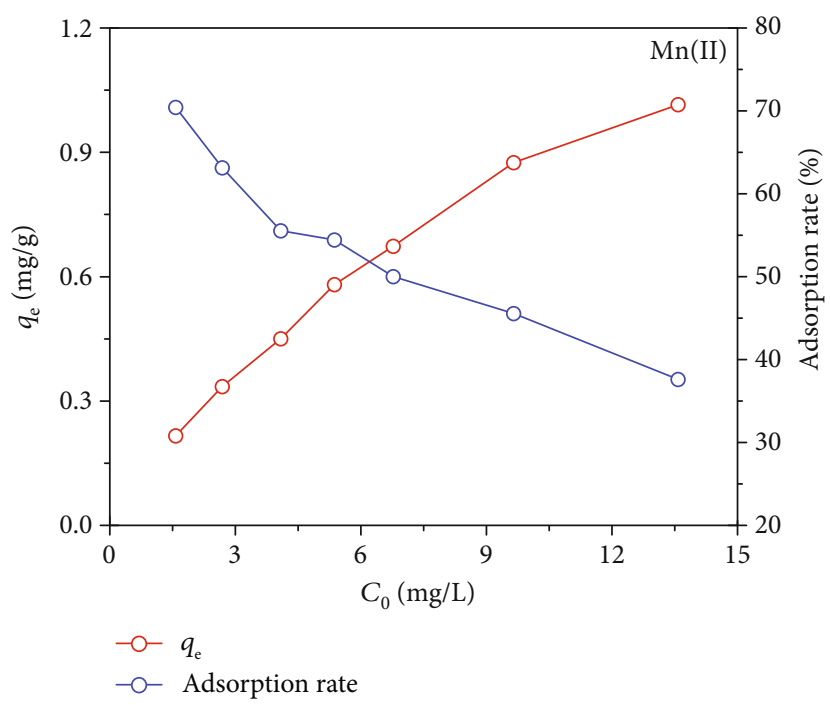

(d)

Figure 6: Adsorption capacity and adsorption rate of $\mathrm{Pb}(\mathrm{II}), \mathrm{Cd}(\mathrm{II}), \mathrm{Cr}(\mathrm{III})$, and $\mathrm{Mn}(\mathrm{II})$ on silty mudstone.

$\mathrm{mol} / \mathrm{L}$. The average adsorption free energy $E(\mathrm{~kJ} / \mathrm{mol})$ can be calculated according to the following formula:

$$
E=\frac{-1}{\sqrt{2 k}} .
$$

The linear form of the D-R model can be expressed as follows:

$$
\ln q_{\mathrm{e}}=\ln q_{\mathrm{m}}-k \varepsilon_{2} .
$$

Linear forms of the Langmuir, Freundlich, and D-R models were used to fit the experimental data (parameters are shown in Table 2), and the models were compared with the experimental data, as shown in Figure 7.

According to the Giles and Smith classification system for isothermal adsorption curves, the adsorptions of $\mathrm{Pb}(\mathrm{II})$,
$\mathrm{Cd}(\mathrm{II})$, and $\mathrm{Mn}(\mathrm{II})$ by silty mudstones belong to the " $\mathrm{L}$ "type class, which is the most typical isothermal class (Figure 7). The adsorption of $\mathrm{Cr}$ (III) can be classified as an " $\mathrm{H}$ "-type, indicating a high affinity between the metal and silty mudstone [28]. The $\mathrm{Pb}(\mathrm{II})$ adsorption models based on Freundlich and D-R equations agreed well with the experimental data, whereas the performance of the Langmuir model was relatively poor (Figure 7 and Table 2). All three models performed well in describing $\mathrm{Cd}(\mathrm{II})$ and $\mathrm{Mn}(\mathrm{II})$ adsorption. The Langmuir model was the best for describing $\mathrm{Cr}$ (III) adsorption, but the performances of the Freundlich and D-R models were poor.

The Freundlich equation does not converge, and although the $\mathrm{D}-\mathrm{R}$ equation can predict the maximum adsorption capacity, the model describes an ideal state, which is difficult to achieve in reality. Therefore, the Langmuir model was used to predict the maximum adsorption 
TABLE 2: Isothermal adsorption parameters.

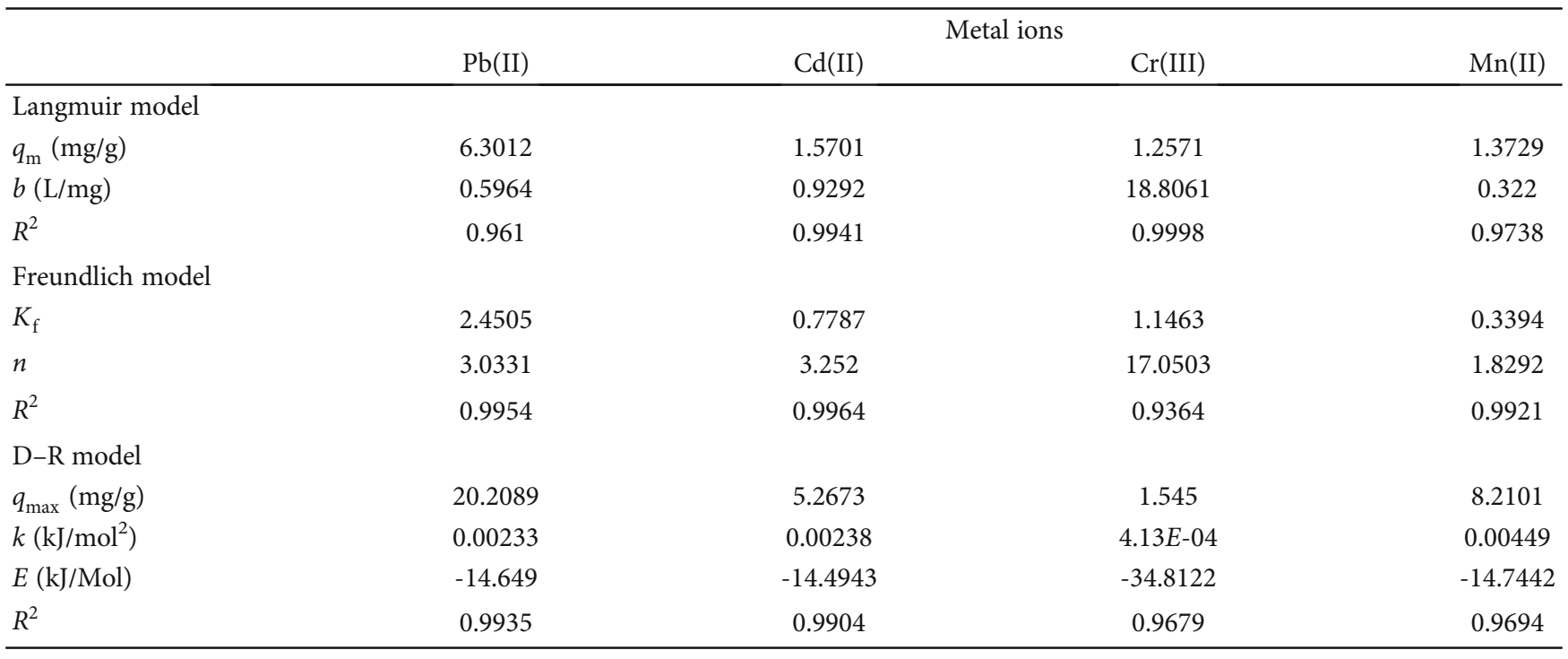

capacities of $\mathrm{Pb}$ (II), $\mathrm{Cd}(\mathrm{II}), \mathrm{Cr}$ (III), and $\mathrm{Mn}$ (II), in which the estimated values were $6.3012,1.5701,1.2571$, and 1.3729, respectively, and the corresponding molar concentrations were $0.03041,0.01397,0.02418$, and $0.02499 \mathrm{mmol} / \mathrm{g}$. Therefore, the adsorptions of $\mathrm{Pb}$ (II) and $\mathrm{Cd}(\mathrm{II})$ were, respectively, highest lowest, and those of $\mathrm{Cr}$ (III) and $\mathrm{Mn}$ (II) were approximately equal.

According to the Freundlich model, adsorption is likely to occur when $2<n<10$; when $n<0.5$, adsorption is less likely to occur [5]. The values of $n$ for the $\mathrm{Pb}$ (II), Cd(II), Cr(III), and Mn(II) models were 3.0331, 3.252, 17.0503 , and 1.8292, respectively, indicating that $\mathrm{Pb}(\mathrm{II})$ and $\mathrm{Cd}(\mathrm{II})$ were likely to be adsorbed, whereas $\mathrm{Mn}$ (II) absorption is less likely to occur. For Cr(III), $n$ was above 10 , indicating that silty mudstone could easily adsorb Cr(III).

In the D-R model, an adsorption free energy value of $|E|<8 \mathrm{~kJ} / \mathrm{mol}$ indicates physical adsorption; values in the range of $8 \leq|E|<18 \mathrm{~kJ} / \mathrm{mol}$ indicate chemisorption [5]. According to the model, the adsorption energies $|E|$ of $\mathrm{Pb}(\mathrm{II}), \mathrm{Cd}(\mathrm{II}), \mathrm{Cr}(\mathrm{III})$, and $\mathrm{Mn}(\mathrm{II})$ were $14.649,14.494$, 34.8122 , and $14.7442 \mathrm{~kJ} / \mathrm{mol}$, respectively, indicating that chemical processes were dominant.

4.3. Rock Surface Adsorption Characteristics. Because waste rocks often appear as large blocks, the adsorption capacity $q_{\mathrm{es}}\left(\mathrm{mg} / \mathrm{dm}^{2}\right)$ per unit area is often employed for engineering applications. Based on adsorption experiments, the concentrations of heavy metal ions before and after a reaction $\left(C_{0}\right.$ and $C_{\mathrm{e}}$ ) and the surface area $S$ of rock samples were obtained, and the adsorption capacity $q_{\mathrm{es}}\left(\mathrm{mg} / \mathrm{dm}^{2}\right)$ was calculated according to Formula (2). According to the equilibrium concentration $C_{e}$, the corresponding equivalent $q_{\mathrm{e}}(\mathrm{mg} / \mathrm{g})$ was calculated using the three equations obtained in Section 4.2 (Table 3). The $q_{\mathrm{e}}$ values for $\mathrm{Cd}(\mathrm{II}), \mathrm{Cr}(\mathrm{III})$, and $\mathrm{Mn}(\mathrm{II})$ calculated by the three equations did not differ vastly; therefore, the average value was used. The $q_{\mathrm{e}}$ value for $\mathrm{Pb}(\mathrm{II})$ was significantly smaller when calculated using the Langmuir equation. Because the Langmuir equation performed poorly in predicting $\mathrm{Pb}(\mathrm{II})$ adsorption compared with the other two models, $q_{\mathrm{e}}$ for $\mathrm{Pb}$ (II) was calculated as the mean of values derived from the Freundlich and D-R equations.

The values of $q_{\mathrm{es}}\left(\mathrm{mg} / \mathrm{dm}^{2}\right)$ and $q_{\mathrm{e}}(\mathrm{mg} / \mathrm{g})$ were positively correlated $\left(q_{\mathrm{e}}=0.064107 q_{\mathrm{es}} ; R^{2}=0.8992\right)$, as shown in Figure 8.

Errors in the fitting equations may be attributed to the following two reasons: (1) differences in the proportion of minerals and elements on the rock surface among experimental groups or heterogeneous rock compositions and (2) different degrees of damage to rock samples caused by soaking and changes in the water-rock contact area.

In Section 4.2, we obtained a function to describe the relationship between $C_{\mathrm{e}}$ and $q_{\mathrm{e}}$; subsequently, the relationship between $q_{\mathrm{e}}$ and $q_{\mathrm{es}}$ was obtained. The saturation adsorption capacities $\left(q_{\mathrm{ms}}\right)$ of $\mathrm{Pb}(\mathrm{II}), \mathrm{Cd}(\mathrm{II}), \mathrm{Cr}(\mathrm{III})$, and $\mathrm{Mn}(\mathrm{II})$ predicted by the Langmuir equation were 98.3, 24.5, 19.6, and $21.4 \mathrm{mg} / \mathrm{dm}^{2}$, respectively.

\section{Prediction of Goaf Adsorption Capacity}

5.1. Adsorption Rate of Goafs. To evaluate the capacity of goafs for purifying water, the Langmuir equation was used to describe the isothermal adsorption curves for $\mathrm{Pb}(\mathrm{II})$, $\mathrm{Cd}(\mathrm{II}), \mathrm{Cr}(\mathrm{III})$, and $\mathrm{Mn}(\mathrm{II})$. Although the Langmuir model's performance in predicting $\mathrm{Pb}(\mathrm{II})$ adsorption was relatively low, it still performed well in predicting $q_{\mathrm{ms}}$. According to the Langmuir equation, the relationship between the adsorption capacity per unit area $q_{\mathrm{es}}\left(\mathrm{mg} / \mathrm{dm}^{2}\right)$ and the equilibrium concentration $C_{e}(\mathrm{mg} / \mathrm{L})$ of the solution can be described as follows:

$$
q_{\mathrm{es}}=\frac{b q_{\mathrm{ms}} C_{\mathrm{e}}}{1+b C_{\mathrm{e}}} .
$$




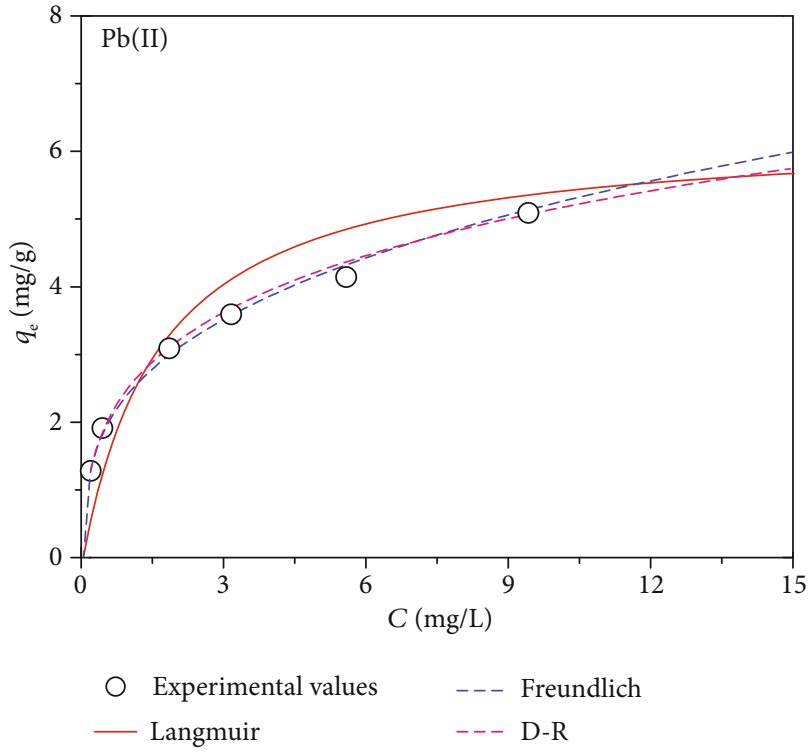

(a)

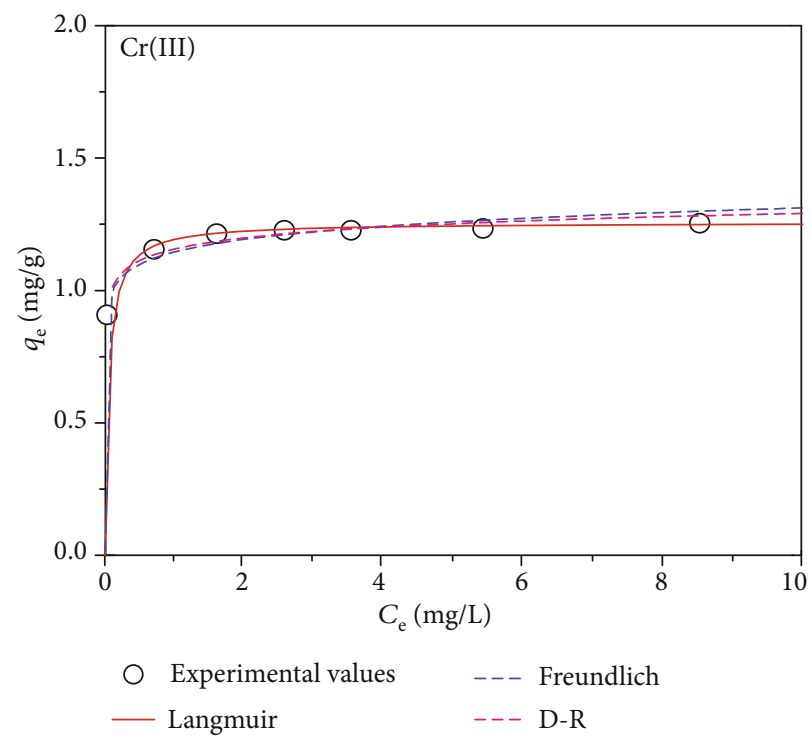

(c)

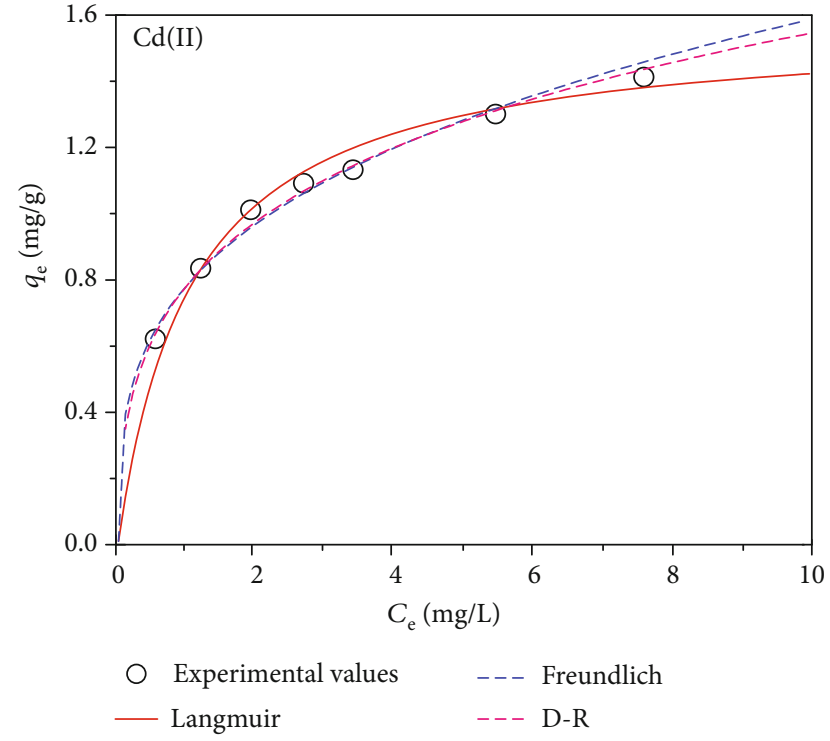

(b)

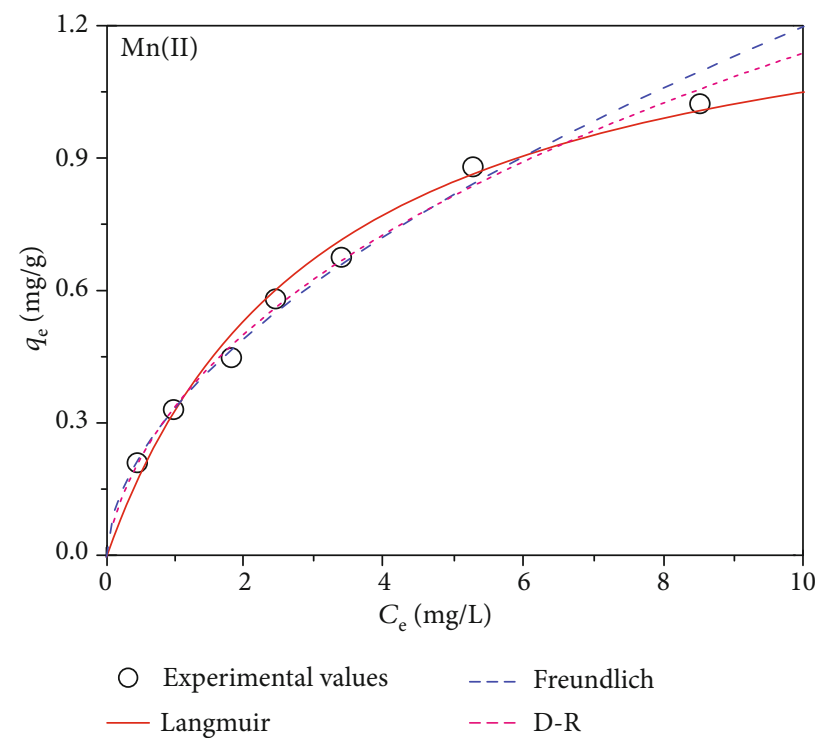

(d)

FIGURE 7: Isothermal adsorption line.

TABLE 3: Adsorption capacity of equivalent mass units.

\begin{tabular}{lcccccc}
\hline Test group & $\mathrm{Pb}$ & $\mathrm{Cd} 1$ & $\mathrm{Cd} 2$ & $\mathrm{Cr}$ & $\mathrm{Mn} 1$ & $\mathrm{Mn} 2$ \\
\hline$C_{\mathrm{e}}(\mathrm{mg} / \mathrm{L})$ & 0.057 & 0.522 & 2.205 & 0.367 & 0.835 & 6.803 \\
$C_{0}(\mathrm{mg} / \mathrm{L})$ & 20.41 & 7.749 & 18.59 & 15.21 & 7.99 & 20.11 \\
$S\left(\mathrm{~cm}^{2}\right)$ & 28.67 & 17.08 & 18.06 & 20.03 & 27.09 & 18.46 \\
$q_{\mathrm{es}}\left(\mathrm{mg} / \mathrm{dm}^{2}\right)$ & 14.2 & 8.46 & 18.14 & 14.82 & 5.28 & 14.42 \\
$q_{\mathrm{e}}(\mathrm{mg} / \mathrm{g})$ & & & & & & \\
Langmuir model & 0.207 & 0.513 & 1.055 & 1.098 & 0.291 & 0.943 \\
Freundlich model & 0.953 & 0.638 & 0.993 & 1.081 & 0.3075 & 0.968 \\
D-R model & 0.859 & 0.625 & 1.000 & 1.094 & 0.308 & 0.948 \\
Mean & 0.906 & 0.592 & 1.016 & 1.091 & 0.3022 & 0.953 \\
\hline
\end{tabular}

The adsorption rate $A$ and the initial concentration $C_{0}(\mathrm{mg} / \mathrm{g})$ can be calculated based on $C_{\mathrm{e}}$ and $q_{\mathrm{es}}$ as follows:

$$
\begin{aligned}
A & =\frac{(S / V) q_{\mathrm{es}}}{(S / V) q_{\mathrm{es}}+C_{\mathrm{e}}}, \\
C_{0} & =(S / V) q_{\mathrm{es}}+C_{\mathrm{e}},
\end{aligned}
$$

where $S\left(\mathrm{dm}^{2}\right)$ is the area of contact between water and rock, $V$ (L) the volume of water, and $f=S / V$ ( $f\left(\mathrm{dm}^{-1}\right)$ the specific surface area of the water body). 


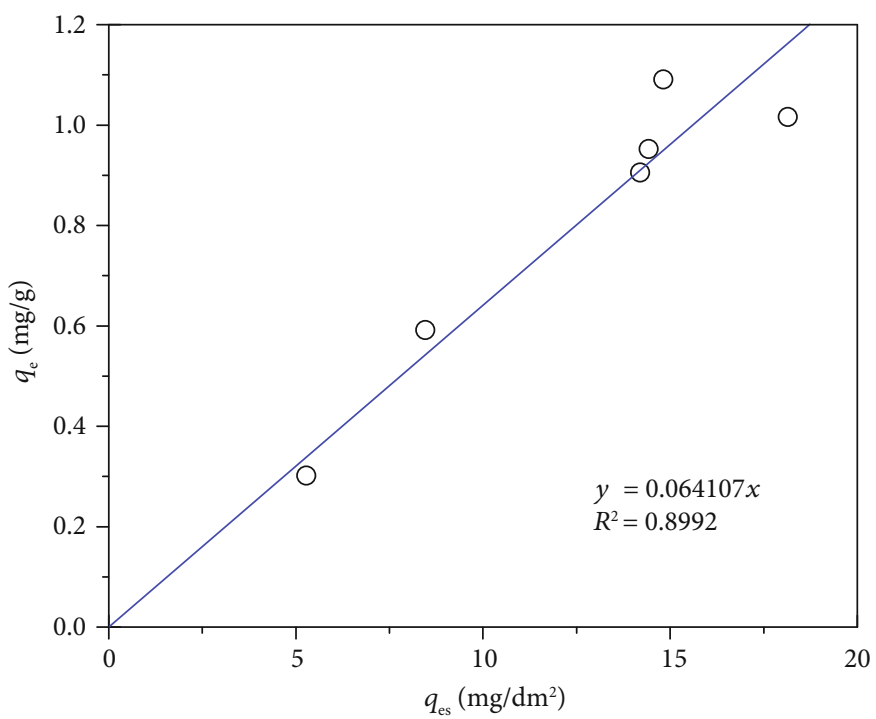

Figure 8: $q_{\mathrm{es}}$ versus $q_{\mathrm{e}}$.

By substituting Formula (11) into Formulas (12) and (13), the variable $C_{\mathrm{e}}$ can be eliminated to obtain

$$
A=\frac{1+b C_{0}+b f q_{\mathrm{ms}}-\sqrt{-4 b^{2} f q_{\mathrm{ms}} C_{0}+\left(1+b C_{0}+b f q_{\mathrm{ms}}\right)^{2}}}{2 b C_{0}} .
$$

Subsequently, Formula (11) is substituted into (13), and Formula (15) can be obtained by a simple transformation and differentiation:

$$
B=\frac{\mathrm{d} C_{0}-\mathrm{d} C_{\mathrm{e}}}{\mathrm{d} C_{0}}=\frac{1}{2}-\frac{1-b f q_{\mathrm{ms}}+b C_{0}}{2 \sqrt{4 b C_{0}+\left(1+b f q_{\mathrm{ms}}-b C_{0}\right)^{2}}},
$$

where $B$ represents the incremental adsorption rate; i.e., the change in adsorption rate as the initial concentration increases by $\Delta C_{0}$. The adsorption rate decreases with increasing concentration. The value of $B$ is the highest when $C_{0}=0$. At this point, Formula (15) can be simplified to the following:

$$
B_{\max }=B\left(C_{0}=0\right)=\frac{1}{2}-\frac{1-b f q_{\mathrm{ms}}}{2\left(1+b f q_{\mathrm{ms}}\right)} .
$$

As shown in Formula (16), the maximum adsorption rate is only related to $b f q_{\mathrm{m}}$; larger $b f q_{\mathrm{m}}$ values correspond to higher $B_{\max }$.

$C_{0}$ can be obtained based on Formula (14):

$$
C_{0}=\frac{q_{\mathrm{ms}}}{A} f-\frac{1}{b A(1-A)}
$$

According to Formula (17), when the adsorption rate $A$ is fixed, the concentration of the solution adsorbed by the waste rock is linearly related to $f$. The greater the $f$ value, the greater the adsorption capacity of waste rock in the goaf.

Formula (14) can be expressed as $A=A\left(C_{0}\right)$. Because water in goafs experiences cyclic discharge and draining events, the existing rock has already absorbed some heavy metals owing to previous water-rock interactions. After the original water is drained, water with a heavy metal concentration of $C_{0 n}(\mathrm{mg} / \mathrm{L})$ is discharged into the goaf. When $C_{0 n}$ $>C_{\mathrm{ec}}\left(C_{\mathrm{ec}}\right.$ is the equilibrium concentration corresponding to $\left.q_{\mathrm{ec}}\right)$, the adsorption reaction will proceed, and the adsorption rate of heavy metals can be calculated as follows:

$$
A=\frac{\left.\left(f q_{\mathrm{ec}}+C_{0 n}\right) A\left(C_{0}\right)\right|_{C_{0}=f q_{\mathrm{ec}}+C_{0 n}}-f q_{\mathrm{ec}}}{C_{0 n}}
$$

When $C_{0 n}=C_{\mathrm{ec}}$, the adsorption reaction will not occur; when $C_{0 n}<C_{\mathrm{ec}}$, heavy metals on the rock surface may be desorbed and released into the water.

5.2. Estimation of Specific Surface Area $f$ in the Goaf. As shown in Figure 9, the water column in the goaf was divided into $n$ rectangular elements of length $\mathrm{d} x$, width $\mathrm{d} y$, and infinite vertical height. Each element has a horizontal crosssectional area of $\mathrm{d} S_{x y}$, which is equal to $\mathrm{d} x \mathrm{~d} y$. The area of contact between a rock in the ith water column and the upper and lower rocks is $\mathrm{d} S_{i 1}$ and $\mathrm{d} S_{i 2}$, respectively; the angle between $S_{i 1}$ and the horizontal plane is $a_{i 1}$; the angle between $S_{i 2}$ and the horizontal plane is $a_{i 2}$; the height of the water column (i.e., the vertical opening of voids between rocks) is $l_{i}$; the water-rock contact area $\mathrm{d} S_{i}=\left(\sec a_{i 1}+\sec a_{i 2}\right) \mathrm{d} x \mathrm{~d} y ; \mathrm{d}$ $V_{i}=l_{i} \mathrm{~d} x \mathrm{~d} y$. Based on this information, the following formulas can be obtained:

$$
S=\int\left[\sum_{i=1}^{n}\left(\frac{1}{\cos a_{i 1}}+\frac{1}{\cos a_{i 2}}\right)\right] \mathrm{d} x \mathrm{~d} y=2 \overline{\operatorname{Sec} a} \int n \mathrm{~d} x \mathrm{~d} y,
$$



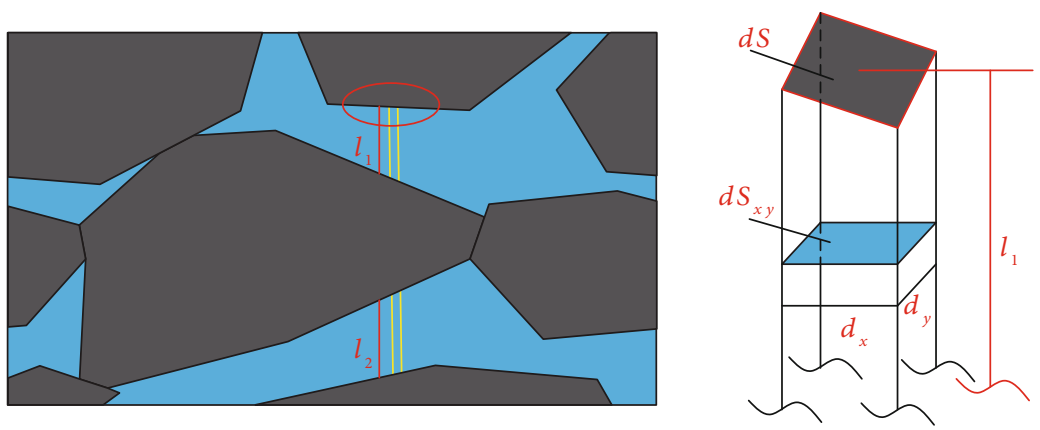

Figure 9: Diagram of a specific surface area of water in the goaf.

$$
V=\int\left(\sum_{i=1}^{n} l_{i}\right) \mathrm{d} x \mathrm{~d} y=\bar{l} \int n \mathrm{~d} x \mathrm{~d} y,
$$

where $\overline{\operatorname{Sec} a}$ is the average secant of angles between all differential cross sections and the horizontal plane in the integral domain; $\bar{l}$ is the mean height of all differential water columns in the integral region (i.e., the mean vertical opening of voids between rocks in the goaf). (20):

Formula (21) can be obtained using Formulas (19) and

$$
f=\frac{S}{V}=\frac{2 \overline{\operatorname{Sec} a}}{\bar{l}} .
$$

Assuming that the angle $a$ has an equal probability of occurring in the range $(0, \pi / 2)$, we can obtain the following relationship:

$$
\overline{\operatorname{Sec} a}=\frac{1}{\int_{0}^{\pi / 2}(1 /(\pi / 2)) \operatorname{Cos} a d a}=\frac{\pi}{2} .
$$

By substituting Formula (22) into (21), we obtain

$$
f=\frac{\pi}{\bar{l}} .
$$

A greater compaction corresponds to a smaller rock size, reduced space between rock blocks, and a larger $f$ value. Because conditions in mined-out areas are complex, it is difficult to confirm the value of $\bar{l}$; therefore, we used a conservative estimate. When the range of $\bar{l}$ is $0.1-1 \mathrm{dm}$, the range of $f$ is $3-30 \mathrm{dm}$. An example to understand the concept of $f$ is as follows: when a cylindrical rock of diameter $25 \mathrm{~mm}$ and height $20 \mathrm{~mm}$ is placed in $200 \mathrm{~mL}$ of water, the measured value of $f$ is $1.276 \mathrm{dm}^{-1}$.

5.3. Analysis of Single Adsorption Characteristics. According to the calculations and analysis above, the $A-C_{0}, B-C_{0}$, and $C_{\mathrm{e}}-C_{0}$ curves for $\mathrm{Pb}(\mathrm{II}), \mathrm{Cd}(\mathrm{II}), \mathrm{Cr}(\mathrm{III})$, and $\mathrm{Mn}(\mathrm{II})$ in the goaf are plotted (Figure 10).

The parameter $B$ represents the adsorption capacity of the goaf. According to the size of $B$, the change in adsorption capacity can be divided into three stages, whose ranges are determined by $C_{0}$.
Stage I represents the nearly complete adsorption stage $\left(B \geq 0.99 B_{\max }\right)$. During this stage, heavy metals in the goaf are almost completely adsorbed. Owing to the high specific surface area of water in the goaf, a small increase in adsorption by the rock surface may result in a substantial reduction in ion concentrations in the water. As long as the rock is not near saturation with respect to ion adsorption, the adsorption rate will remain high. As $C_{0}$ increases, the changes in $C_{\mathrm{e}}, A$, and $B$ are extremely slow.

During Stage II (the adsorption decay stage; $0.99 B_{\max }>$ $B \geq 0.01$ ), the adsorption capacity of the goaf decreases and it reaches zero. This stage can be further categorized into the strong adsorption stage $\left(0.99 B_{\max }>B \geq 0.75\right)$, substrong adsorption stage $(0.75>B \geq 0.50)$, subweak adsorption stage $(0.50>B \geq 0.25)$, and weak adsorption stage $(0.25>B \geq 0.01)$. During the strong and weak adsorption stages, the adsorption capacity decreases slowly; during the substrong and subweak adsorption stages, the adsorption capacity decreases rapidly. At this stage, the $B-C_{0}$ curve drops rapidly with $B$ decreasing from approximately 1 to approximately 0 . The slope of the $A-C_{0}$ curve is smaller, and the overall decrease in $A$ is relatively slow. By contrast, the $C_{\mathrm{e}}-C_{0}$ curve increases significantly midway through Stage II.

At Stage III (the zero adsorption stage; $B<0.01$ ), the goaf's adsorption capacity is nearly exhausted and the total adsorption no longer increases with $C_{0}$. The value of $B$ remains constant at $\sim 0, C_{\mathrm{e}}$ increases with increasing $C_{0}$, and $A$ further decreases.

The adsorption characteristics of $\mathrm{Pb}(\mathrm{II}), \mathrm{Cd}(\mathrm{II}), \mathrm{Cr}(\mathrm{III})$, and $\mathrm{Mn}$ (II) at $f=15$ were determined based on Figures 10(a), 10(c), 10(e), and 10(g), respectively (Table 4).

The near-complete adsorption stage represents the optimal adsorption range, and the strong adsorption stage represents the suboptimal adsorption range. The range of $C_{0}$ is wide within these two stages. As shown in Table 4, the optimal adsorption ranges of $\mathrm{Pb}(\mathrm{II}), \mathrm{Cd}(\mathrm{II}), \mathrm{Cr}(\mathrm{III})$, and $\mathrm{Mn}$ (II) in the goaf are $0-983,0-170,0-255$, and $0-101 \mathrm{mg} / \mathrm{L}$, respectively, and their suboptimal adsorption ranges are 983-1415, 170-343, 255-289, and 101-281 mg/L, respectively. The upper limit of the optimal adsorption range reflects the optimal purification capacity of the goaf, and the upper limit of the suboptimal adsorption range represents the suboptimal purification capacity. The optimal purification capacities of $\mathrm{Pb}(\mathrm{II}), \mathrm{Cd}(\mathrm{II}), \mathrm{Cr}(\mathrm{III})$, and $\mathrm{Mn}(\mathrm{II})$ are 983, 170, 255, and $101 \mathrm{mg} / \mathrm{L}$, respectively, and their suboptimal purification 


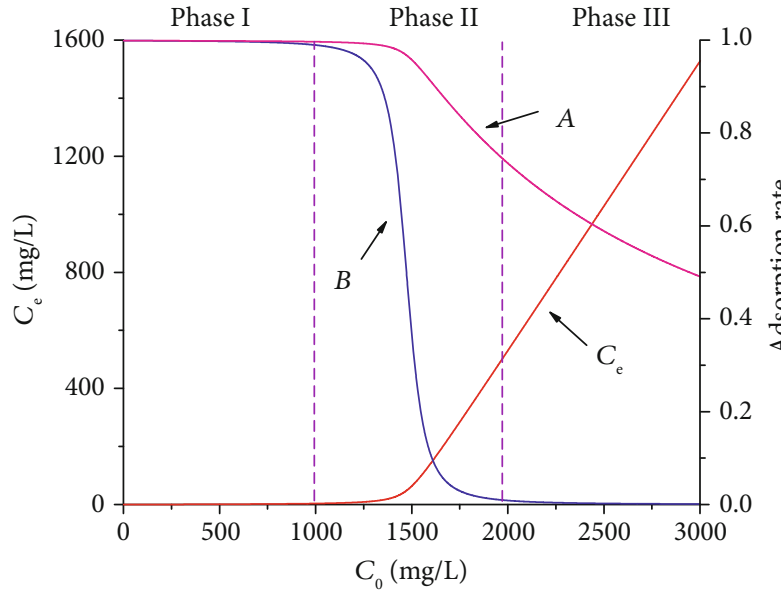

(a)

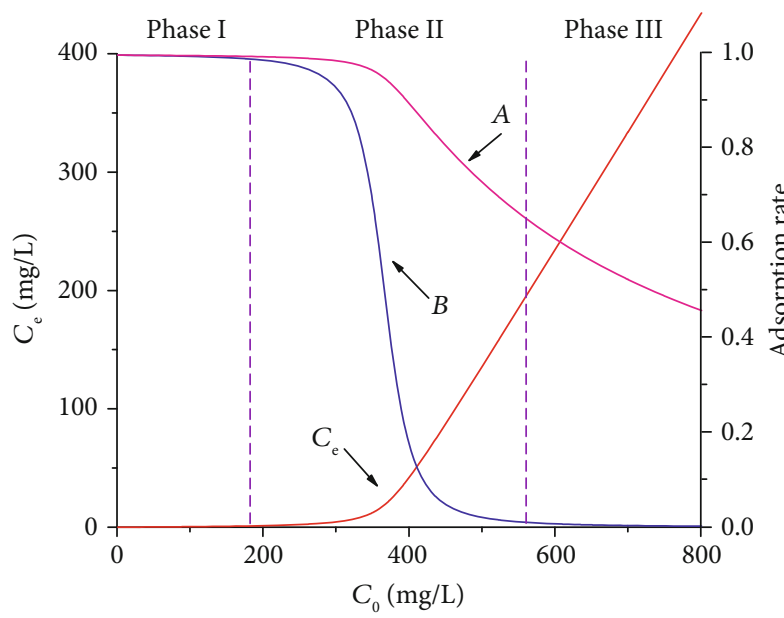

(c)

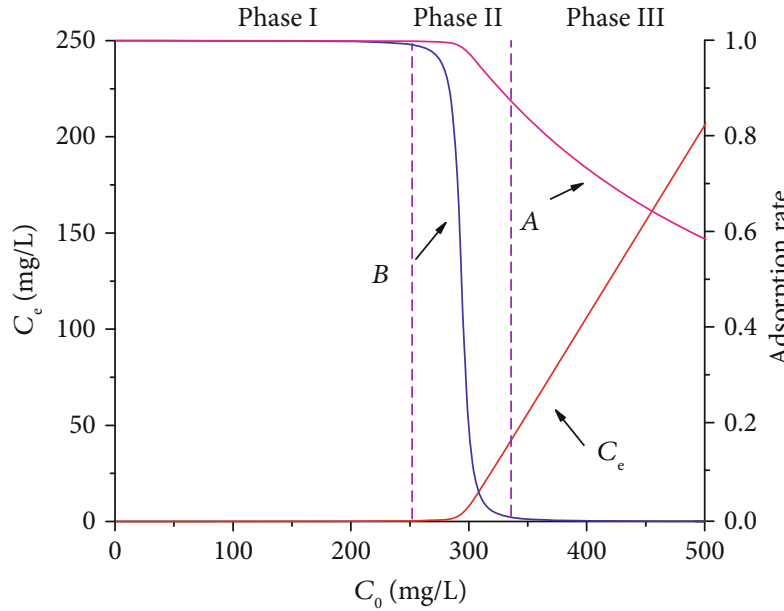

(e)

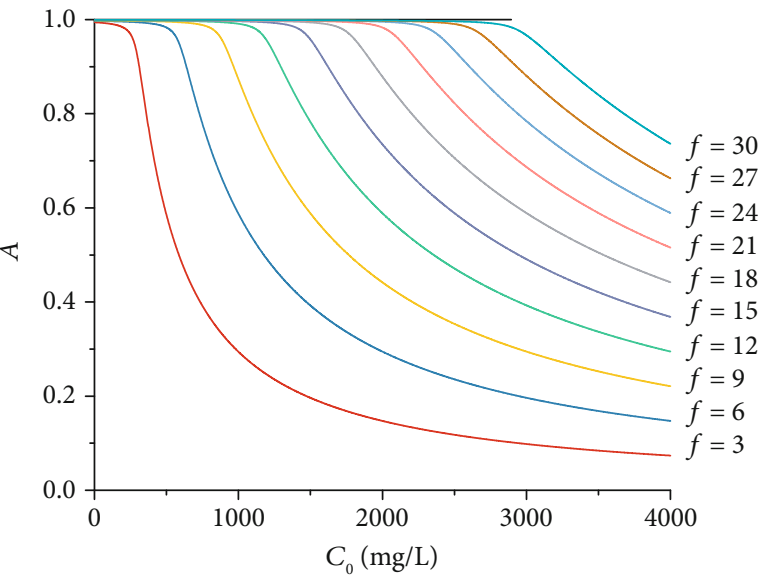

(b)

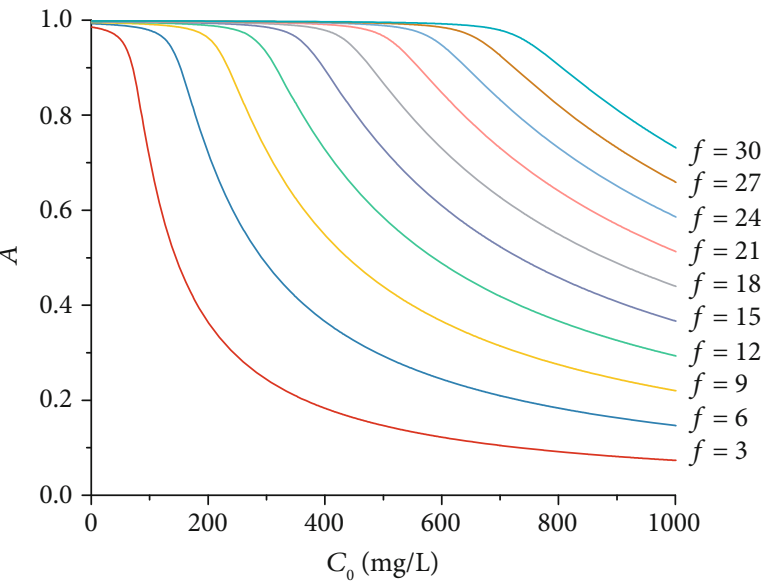

(d)

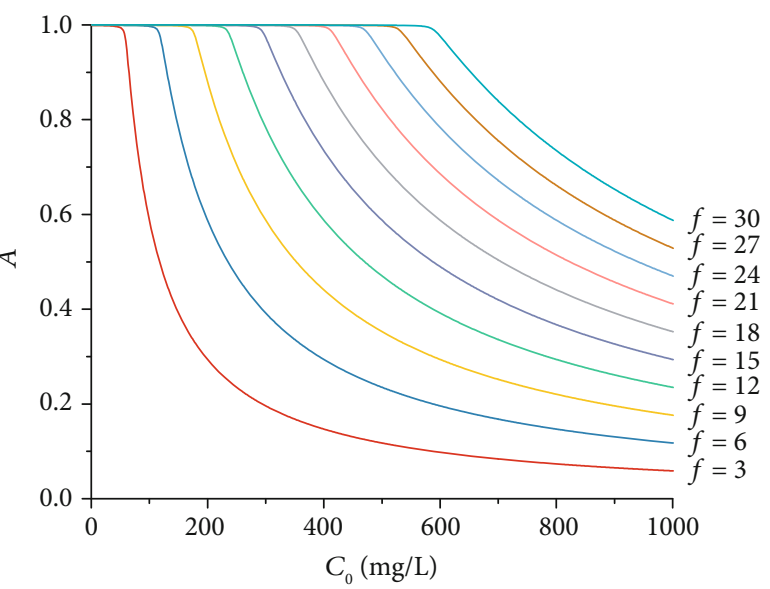

(f)

Figure 10: Continued. 


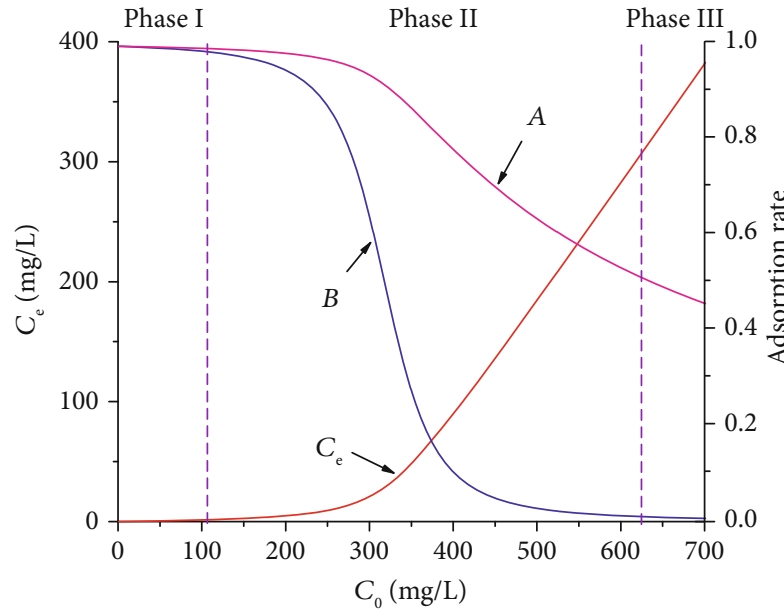

(g)

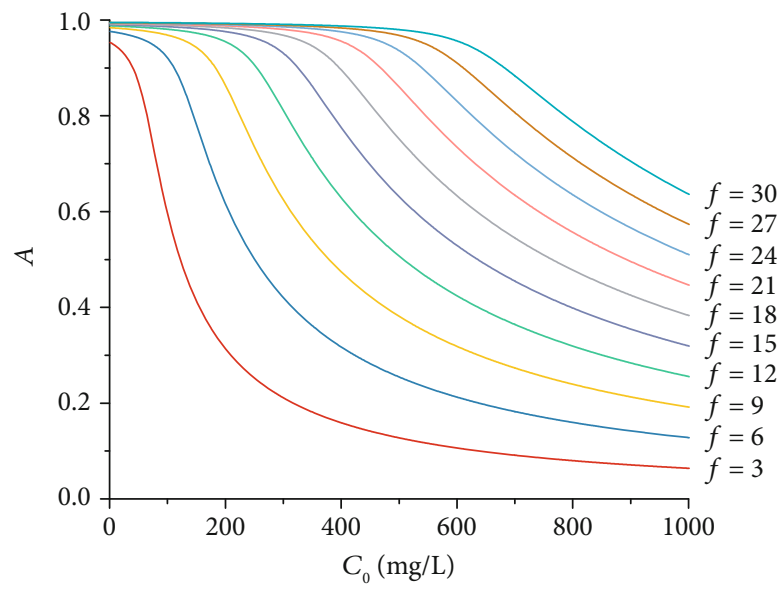

(h)

FIgURe 10: Adsorption curves for heavy metals in the mined-out area. (a) $\mathrm{Pb}$ (II), $f=15$. (b) $\mathrm{Pb}$ (II), $f=3 \sim 30$. (c) $\mathrm{Cd}$ (II), $f=15$. (d) Cd(II), $f=3 \sim 30$. (e) $\operatorname{Cr}$ (III), $f=15$. (f) $\operatorname{Cr}$ (III), $f=3 \sim 30$. (g) $M n(I I), f=15$. (h) Mn(II), $f=3 \sim 30$.

TABLE 4: Ranges of adsorption phases at $f=15$.

\begin{tabular}{|c|c|c|c|c|c|c|c|}
\hline \multirow[b]{2}{*}{ Ions } & \multirow[b]{2}{*}{ Parameters } & \multirow{2}{*}{$\begin{array}{c}\text { I } \\
\text { Near-complete } \\
\text { adsorption }\end{array}$} & \multicolumn{4}{|c|}{$\begin{array}{c}\text { II } \\
\text { Absorption attenuation }\end{array}$} & \multirow{2}{*}{$\begin{array}{c}\text { III } \\
\text { Zero } \\
\text { adsorption }\end{array}$} \\
\hline & & & $\begin{array}{l}\text { Strong } \\
\text { adsorption }\end{array}$ & $\begin{array}{l}\text { Absorpti } \\
\text { Substrong } \\
\text { adsorption }\end{array}$ & $\begin{array}{l}\text { luation } \\
\text { Subweak } \\
\text { adsorption }\end{array}$ & $\begin{array}{c}\text { Weak } \\
\text { adsorption }\end{array}$ & \\
\hline \multirow{4}{*}{$\mathrm{Pb}(\mathrm{II})$} & $C_{0}(\mathrm{mg} / \mathrm{L})$ & $<983$ & $<1415$ & $<1472$ & $<1530$ & $<1962$ & $>1962$ \\
\hline & $C_{\mathrm{e}}(\mathrm{mg} / \mathrm{L})$ & $<3.32$ & $<26.93$ & $<47.64$ & $<84.27$ & $<492.50$ & $>492.50$ \\
\hline & $A$ & $>0.997$ & $>0.981$ & $>0.967$ & $>0.945$ & $>0.749$ & $<0.749$ \\
\hline & $B$ & $>0.99$ & $>0.75$ & $>0.50$ & $>0.25$ & $>0.01$ & $<0.01$ \\
\hline \multirow{4}{*}{ Cd(II) } & $C_{0}(\mathrm{mg} / \mathrm{L})$ & $<170$ & $<343$ & $<366$ & $<392$ & $<562$ & $>562$ \\
\hline & $C_{\mathrm{e}}(\mathrm{mg} / \mathrm{L})$ & $<0.90$ & $<10.29$ & $<18.60$ & $<35.36$ & $<196.50$ & $>196.50$ \\
\hline & $A$ & $>0.995$ & $>0.970$ & $>0.949$ & $>0.910$ & $>0.650$ & $<0.650$ \\
\hline & $B$ & $>0.99$ & $>0.75$ & $>0.50$ & $>0.25$ & $>0.01$ & $<0.01$ \\
\hline \multirow{4}{*}{ Cr(III) } & $C_{0}(\mathrm{mg} / \mathrm{L})$ & $<255$ & $<289$ & $<294$ & $<299$ & $<332$ & $>332$ \\
\hline & $C_{\mathrm{e}}(\mathrm{mg} / \mathrm{L})$ & $<0.34$ & $<2.14$ & $<3.93$ & $<7.17$ & $<38.41$ & $>38.41$ \\
\hline & $A$ & $>0.999$ & $>0.993$ & $>0.987$ & $>0.976$ & $>0.884$ & $<0.884$ \\
\hline & $B$ & $>0.99$ & $>0.75$ & $>0.50$ & $>0.25$ & $>0.01$ & $<0.01$ \\
\hline \multirow{4}{*}{$\mathrm{Mn}(\mathrm{II})$} & $C_{0}(\mathrm{mg} / \mathrm{L})$ & $<101$ & $<281$ & $<318$ & $<354$ & $<628$ & $>628$ \\
\hline & $C_{\mathrm{e}}(\mathrm{mg} / \mathrm{L})$ & $<1.40$ & $<15.01$ & $<28.52$ & $<51.32$ & $<310.18$ & $>310.18$ \\
\hline & $A$ & $>0.986$ & $>0.947$ & $>0.910$ & $>0.855$ & $>0.506$ & $<0.506$ \\
\hline & $B$ & $>0.98$ & $>0.75$ & $>0.50$ & $>0.25$ & $>0.01$ & $<0.01$ \\
\hline
\end{tabular}

capacities are $1415,343,289$, and $281 \mathrm{mg} / \mathrm{L}$, respectively. The optimal purification capacities were corrected according to Formula (17) for the case of $f \neq 15$ ( $A$ is constant): $\{983+98.6(f-15)\},\{170+24.6(f-15)\},\{255+19.6(f-15)\}$, $\{101+21.7(f-15)\} \mathrm{mg} / \mathrm{L}$, and the suboptimal purification capacity were corrected to $\{1415+100.2(f-15)\},\{343+$ $25.3(f-15)\},\{289+19.7(f-15)\}$, and $\{281+22.6(f-15)\}$ $\mathrm{mg} / \mathrm{L}$, respectively.

5.4. Analysis of Cyclic Adsorption Characteristics. As demonstrated in Section 5.3, the goaf has a high capacity for
$\mathrm{Pb}(\mathrm{II}), \mathrm{Cd}(\mathrm{II}), \mathrm{Cr}(\mathrm{III})$, and $\mathrm{Mn}(\mathrm{II})$ adsorption. However, the heavy metal concentrations in the natural environment may be much smaller than those investigated in the analysis. To investigate the adsorption characteristics during cyclic discharge events, we considered the following case: heavy metal polluted water with an initial concentration of $C_{0}=\gamma$ is discharged into the goaf, and this water is drained out when the reaction reaches equilibrium. Heavy metal-polluted water with the same initial concentration is again discharged into the goaf and exhausted when the reaction reaches equilibrium. If this cycle is repeated for 

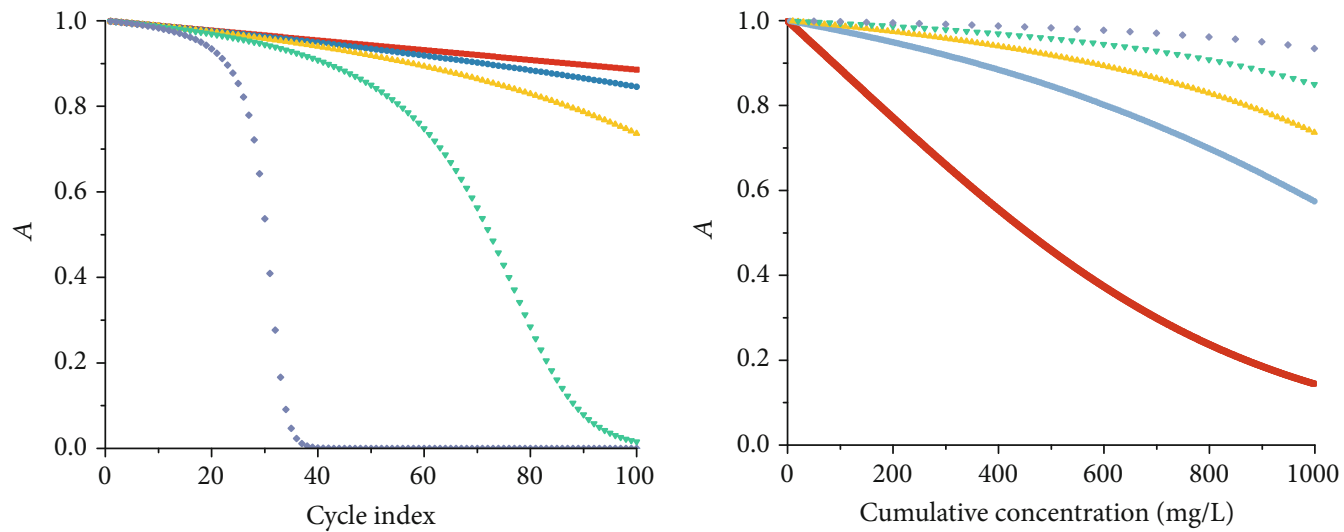

$$
\begin{array}{ll}
C_{0}=1 & \nabla C_{0}=20 \\
\text { - } C_{0}=5 & \rightarrow C_{0}=50 \\
C_{0}=10 &
\end{array}
$$

(a)

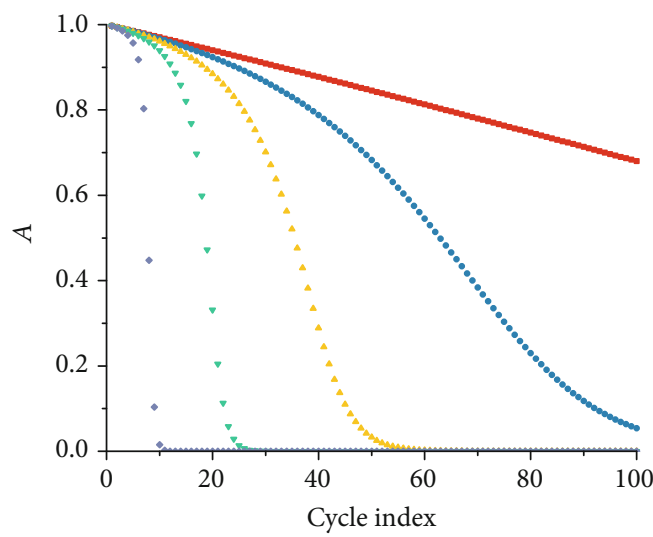

- $C_{0}=1$

- $C_{0}=5$

$\triangle C_{0}=10$

$\nabla C_{0}=20$

- $C_{0}=50$

(c)

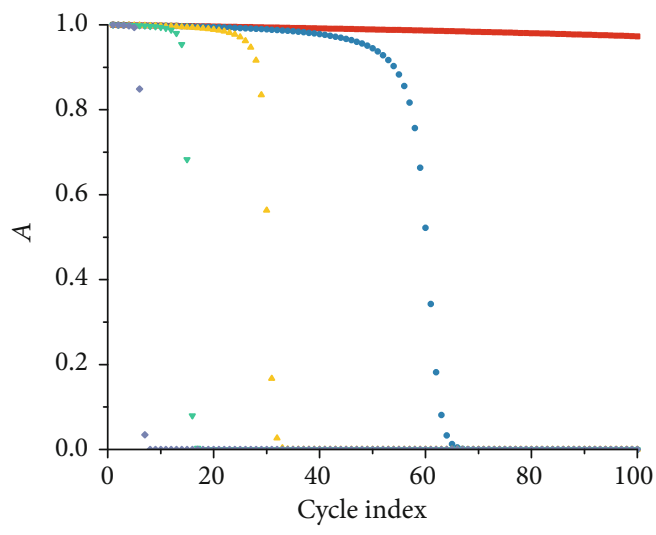

$$
\begin{array}{ll}
\text { - } C_{0}=1 & \nabla C_{0}=20 \\
\text { - } C_{0}=5 & \forall C_{0}=50 \\
\triangle C_{0}=10 &
\end{array}
$$

(b)

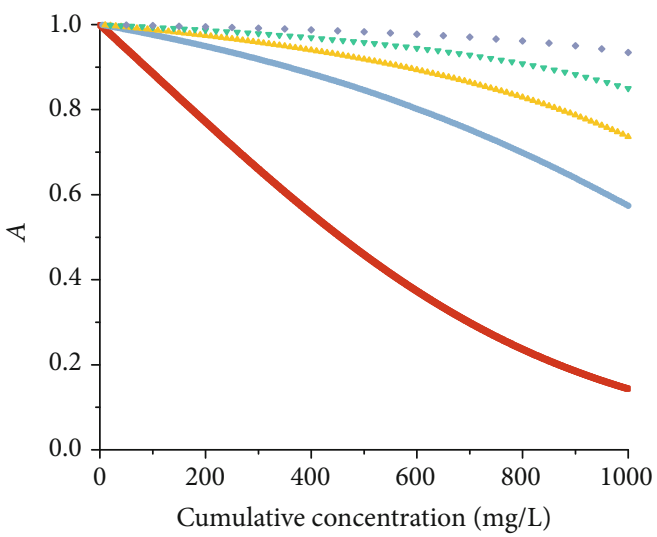

$$
\begin{array}{ll}
C_{0}=1 & \nabla C_{0}=20 \\
\text { - } C_{0}=5 & \rightarrow C_{0}=50 \\
C_{0}=10 &
\end{array}
$$

(d)

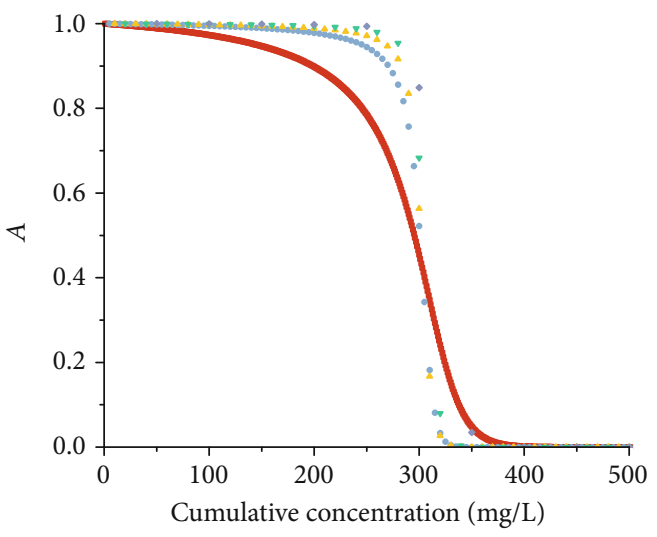

$$
\begin{array}{ll}
\text { - } C_{0}=1 & \nabla C_{0}=20 \\
\text { - } C_{0}=5 & \forall C_{0}=50 \\
\triangle C_{0}=10 &
\end{array}
$$

(f)

(e)

Figure 11: Continued. 


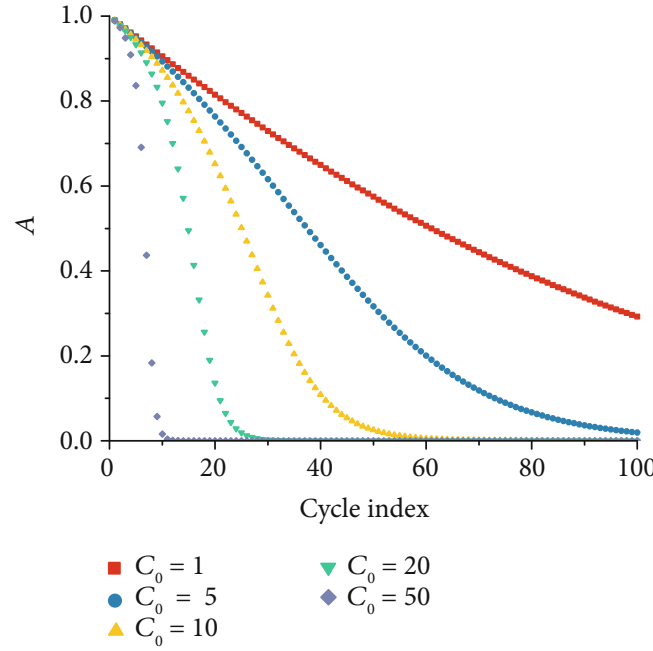

(g)

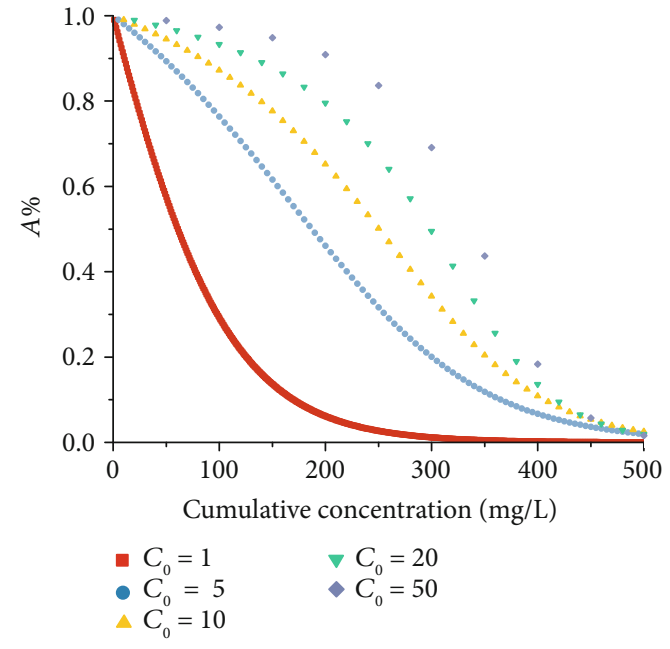

(h)

Figure 11: Cyclic adsorption curves. (a) $\mathrm{Pb}(\mathrm{II}), f=15$. (b) $\mathrm{Pb}(\mathrm{II}), f=15$. (c) $\mathrm{Cd}(\mathrm{II}), f=15$. (d) $\mathrm{Cd}(\mathrm{II}), f=15$. (e) $\mathrm{Cr}$ (III), $f=15$. (f) $\mathrm{Cr}$ (III), $f=15$. (g) $\mathrm{Mn}(\mathrm{II}), f=15$. (h) $\mathrm{Mn}(\mathrm{II}), f=15$.

$n$ cycles, the adsorption rate of the goaf during the $n$th cycle can be calculated according to Formula (18). The cyclic adsorption curve is shown in Figure 11. The parameter $A$ indicates the adsorption rate of the goaf in the $n$th cycle, and the cumulative concentration is the product of the number of cycles $n$ and the initial concentration $\gamma$.

The current adsorption concentration of the rock surface is referred to as the "starting concentration" and is equal to the equilibrium concentration corresponding to the current adsorption amount. The initial heavy metal concentration of the solution minus the starting concentration is referred to as the "effective concentration," which eventually reaches equilibrium. Adsorption by the goaf depends only on the effective concentration. For the cyclic process described above, the ratio of the effective concentration to the initial concentration of the solution is equal to the adsorption rate of the previous cycle. If the adsorption rate of the effective concentration during the $n$th cycle is $x_{n}$, then $A_{n}=A_{n-1} x_{n}$; that is, the adsorption rate $A_{n}$ for each cycle is equal to the product of $A_{n-1}$ (the ratio of the effective concentration to the initial concentration of the solution) and $x_{n}$. As $n$ increases, $x_{n}$ decreases and the proportion of the effective concentration $A_{n-1}$ is reduced. Based on the relationships $A_{1}=x_{1}$ and $A_{n}=A_{n-1} x_{n}, A_{n}$ can be expressed as $A_{n}=x_{1} x_{2}$ $x_{3} \cdots x_{n}$. The greater the number of cycles, the lower the adsorption capacity of the goaf. Using $\mathrm{Mn}(\mathrm{II})$ as an example, $B_{\max }=0.9904$. No matter how small the initial concentration is, the adsorption rate of the 10th cycle must be less than $0.908\left(A_{n}<0.9904^{n}\right)$.

As shown in Figures 11(a), 11(c), 11(e), and 11(g), a higher $C_{0}$ corresponds to a lower adsorption rate when the number of cycles is the same. When $C_{0}$ is low, the accumulation of heavy metals on the rock surface is slow and the adsorption performance of the goaf is slow. As the number of cycles increases, the adsorption rate gradually decreases. In this case, the adsorption rate is primarily affected by the number of cycles and can be estimated as $A_{n}=A_{1}{ }^{n}$. The estimation error increases with $n$ and $C_{0}$. As $C_{0}$ increases, the heavy metal accumulation rate accelerates and the adsorption of the goaf increases rapidly. The adsorption rate declines rapidly with increasing $n$. When the cumulative concentration is the same, a greater $n$ corresponds to a lower $C_{0}$ and a reduced adsorption rate (Figures 11(b), 11(d), 11(f), and 11(h)), indicating that more discharge cycles are unfavorable to water purification. To maximize the purification performance of mined-out areas, the content of heavy metals should be maximum.

\section{Conclusions}

The appearance, mineral composition, and elemental composition of silty mudstones in the No. 3-1 mined-out area of the Ulan Mulun coal mine were analyzed. Batch adsorption experiments were conducted to investigate the isothermal adsorption and kinetic characteristics of $\mathrm{Pb}(\mathrm{II})$, $\mathrm{Cd}(\mathrm{II}), \mathrm{Cr}(\mathrm{III})$, and $\mathrm{Mn}(\mathrm{II})$ adsorption by silty mudstone particles. The adsorption characteristics of the rock surface per unit area were investigated by combining rock block adsorption and particle adsorption tests. The adsorption characteristics of $\mathrm{Pb}(\mathrm{II}), \mathrm{Cd}(\mathrm{II}), \mathrm{Cr}(\mathrm{III})$, and $\mathrm{Mn}(\mathrm{II})$ in the goaf were discussed, and the main conclusions are as follows:

(1) The Freundlich and D-R models performed well in describing $\mathrm{Pb}(\mathrm{II})$ adsorption, whereas the performance of the Langmuir model was relatively poor (Figure 7 and Table 2). All three models performed well in describing $\mathrm{Cd}(\mathrm{II})$ and $\mathrm{Mn}$ (II) adsorption. The Langmuir model was the best for describing $\mathrm{Cr}$ (III) adsorption, but the performances of the Freundlich and D-R models were poor 
(2) The saturation adsorption capacities of silty mudstones for $\mathrm{Pb}(\mathrm{II}), \mathrm{Cd}(\mathrm{II}), \mathrm{Cr}(\mathrm{III})$, and $\mathrm{Mn}(\mathrm{II})$ were $6.3012,1.5701,1.2571$, and $1.3729 \mathrm{mg} / \mathrm{g}$, respectively. The corresponding saturation adsorption capacities per unit rock area were 98.3, 24.5, 19.6, and $21.4 \mathrm{mg} / \mathrm{dm}^{2}$, respectively

(3) The ratio of the water-rock contact area to the volume of water in the goaf could be calculated as $f=2 \overline{\operatorname{Sec} a} / \bar{l}$. Assuming that the angle $a$ had an equal probability of occurring over the interval $(0, \pi / 2)$, the formula could be reduced to $f=\pi \bar{l}$

(4) According to the initial heavy metal concentration in solution, adsorption in the goaf could be categorized into three stages: near-complete adsorption, adsorption attenuation, and zero adsorption. The adsorption decay stage could be subdivided into the strong adsorption, substrong adsorption stage, subweak adsorption, and weak adsorption stages. The optimal and suboptimal purification capacities for $\mathrm{Pb}(\mathrm{II})$, $\mathrm{Cd}(\mathrm{II}), \mathrm{Cr}(\mathrm{III})$, and $\mathrm{Mn}(\mathrm{II})$ in goafs were determined, and a concrete formula was provided to estimate these values

(5) In goafs that were repeatedly used to treat heavy metal-contaminated water, the adsorption rates were lower when the heavy metal concentrations were smaller

\section{Data Availability}

The data used to support the findings of this study are included within the article.

\section{Conflicts of Interest}

The authors declare that there is no conflict of interest regarding the publication of this paper.

\section{Acknowledgments}

This work was financially supported by "the Fundamental Research Funds for the Central Universities" (2018XKQYMS10).

\section{References}

[1] N. R. Axtell, S. P. Sternberg, and K. Claussen, "Lead and nickel removal using Microspora and Lemna minor," Bioresource Technology, vol. 89, no. 1, pp. 41-48, 2003.

[2] N. Ahalya, T. V. Ramachandra, and R. D. Kanamadi, "Biosorption of heavy metals," Res. J. Chem. Environ, vol. 7, no. 4, pp. 71-79, 2003.

[3] D. Ozdes, et al.A. Gundogdu, B. Kemer, C. Duran, H. B. Senturk, and M. Soylak, "Removal of $\mathrm{Pb}(\mathrm{II})$ ions from aqueous solution by a waste mud from copper mine industry: equilibrium, kinetic and thermodynamic study," Journal of Hazardous Materials, vol. 166, no. 2-3, pp. 1480-1487, 2009.
[4] D. L. Sparks, "Sorption Phenomena on Soils," in Environmental Soil Chemistry, L. Sparks Donald, Ed., pp. 133-186, Academic Press, Burlington, 2nd Ed edition, 2003.

[5] D. Ozdes, C. Duran, and H. B. Senturk, "Adsorptive removal of $\mathrm{Cd}(\mathrm{II})$ and $\mathrm{Pb}(\mathrm{II})$ ions from aqueous solutions by using Turkish illitic clay," Journal of Environmental Management, vol. 92, no. 12, pp. 3082-3090, 2011.

[6] I. Heidmann, I. Christl, and R. Kretzschmar, "Aggregation kinetics of kaolinite-fulvic acid colloids as affected by the sorption of $\mathrm{Cu}$ and $\mathrm{Pb}$," Environmental Science \& Technology, vol. 39, no. 3, pp. 807-813, 2005.

[7] I. Heidmann, I. Christl, C. Leu, and R. Kretzschmar, "Competitive sorption of protons and metal cations onto kaolinite: experiments and modeling," Journal of Colloid and Interface Science, vol. 282, no. 2, pp. 270-282, 2005.

[8] G. Sposito, The Chemistry of Soils, Oxford university press, 1989.

[9] J. A. Davis, "Surface complexation modeling in aqueous geochemistry," Mineral-water Interface Geochemistry, vol. 23, pp. 177-259, 1990.

[10] D. R. Brookshaw, V. S. Coker, J. R. Lloyd, D. J. Vaughan, and R. A. Pattrick, "Redox interactions between $\mathrm{Cr}(\mathrm{VI})$ and $\mathrm{Fe}(\mathrm{II})$ in bioreduced biotite and chlorite," Environmental Science \& Technology, vol. 48, no. 19, pp. 11337-11342, 2014.

[11] J. U. Kennedy Oubagaranadin and Z. V. P. Murthy, "Adsorption of divalent lead on a montmorillonite-illite type of clay," Industrial \& Engineering Chemistry Research, vol. 48, no. 23, pp. 10627-10636, 2009.

[12] C. Green-Ruiz, "Effect of salinity and temperature on the adsorption of $\mathrm{Hg}(\mathrm{II})$ from aqueous solutions by a Ca-montmorillonite," Environmental Technology, vol. 30, no. 1, pp. 63-68, 2009.

[13] K. G. Bhattacharyya and S. S. Gupta, "Adsorptive accumulation of $\mathrm{Cd}(\mathrm{II}), \mathrm{Co}(\mathrm{II}), \mathrm{Cu}(\mathrm{II}), \mathrm{Pb}(\mathrm{II})$, and $\mathrm{Ni}(\mathrm{II})$ from water on montmorillonite: influence of acid activation," Journal of Colloid and Interface Science, vol. 310, no. 2, pp. 411-424, 2007.

[14] K. G. Bhattacharyya and S. S. Gupta, "Influence of acid activation of kaolinite and montmorillonite on adsorptive removal of Cd(II) from water," Industrial \& Engineering Chemistry Research, vol. 46, no. 11, pp. 3734-3742, 2007.

[15] I. F. Vasconcelos, B. A. Bunker, and R. T. Cygan, "Molecular dynamics modeling of ion adsorption to the basal surfaces of kaolinite," Journal of Physical Chemistry C, vol. 111, no. 18, pp. 6753-6762, 2007.

[16] L. Benyahya and J.-M. Garnier, "Effect of salicylic acid upon trace-metal sorption (CdII, ZnII, CoII, and MnII) onto alumina, silica, and kaolinite as a function of $\mathrm{pH}$," Environmental Science \& Technology, vol. 33, no. 9, pp. 1398-1407, 1999.

[17] L.-q. Ma, D. S. Zhang, X. Li, G. W. Fan, and Y. F. Zhao, "Technology of groundwater reservoir construction in goafs of shallow coalfields," Mining Science and Technology (China), vol. 19, no. 6, pp. 730-735, 2009.

[18] F. Li-li, Y.-1. Zhu, S. Ai-qin, and S.-z. Chen, "The flocculation research on treating suspended solids contained mine drainage through goaf," Journal of Coal Science \& Engineering (China), vol. 2, pp. 51-54, 2005.

[19] S. Li-nan and C. Guo-qiang, "Evaluation of heavy metal pollution prevention technology based on AHP-FCE," in International Conference on Biological Engineering and Pharmacy 
2016 (BEP 2016), Y. Chao, W. F. Zhang, and X. Li, Eds., pp. 223-226, Atlantis Press, 2016.

[20] L. Zhang, A. Chen, H. Qu, S. Xu, X. Zhang, and X. He, "Fe and Mn removal from mining drainage using goaf filling materials obtained from coal mining process," Water Science and Technology, vol. 72, no. 11, pp. 1940-1947, 2015.

[21] S. Tao, X. Bi-wan, and S. Hui-sheng, "The evolution of coal gangue (CG)-calcium hydroxide $(\mathrm{CH})$-gypsum-H2O system," Materials and Structures, vol. 41, no. 7, pp. 1307-1314, 2008.

[22] M. Peiravi, S. R. Mote, M. K. Mohanty, and J. Liu, "Bioelectrochemical treatment of acid mine drainage (AMD) from an abandoned coal mine under aerobic condition," Journal of Hazardous Materials, vol. 333, pp. 329-338, 2017.

[23] E. Fosso-Kankeu, A. Manyatshe, and F. Waanders, "Mobility potential of metals in acid mine drainage occurring in the Highveld area of Mpumalanga Province in South Africa: implication of sediments and efflorescent crusts," International Biodeterioration \& Biodegradation, vol. 119, pp. 661670, 2017.

[24] Y. Li, J.-d. Wang, X.-j. Wang, and J.-f. Wang, "Adsorptiondesorption of $\mathrm{Cd}(\mathrm{II})$ and $\mathrm{Pb}(\mathrm{II})$ on Ca-Montmorillonite," Industrial \& Engineering Chemistry Research, vol. 51, no. 18, pp. 6520-6528, 2012.

[25] I. Langmuir, "The adsorption of gases on plane surfaces of glass, mica and platinum," Journal of the American Chemical Society, vol. 40, no. 9, pp. 1361-1403, 1918.

[26] H. Freundlich, "Über die Adsorption in Lösungen," Zeitschrift für Physikalische Chemie, vol. 57U, no. 1, p. 385, 1907.

[27] M. Dubinin and L. V. Radushkevich, "The equation of the characteristic curve of activated charcoal," Proceedings of the Academy of Sciences of the USSR: Physical Chemistry Section, vol. 55, no. 1, pp. 331-337, 1947.

[28] C. H. Giles, D. Smith, and A. Huitson, "A general treatment and classification of the solute adsorption isotherm. I. Theoretical," Journal of Colloid and Interface Science, vol. 47, no. 3, pp. 755-765, 1974. 